\title{
Rhythm of Daily Activity and Behavior of European Bison in the Biatowieza Forest in the Period without Snow Cover
}

\author{
Krystyna CABOŃ-RACZYÑSKA, Malgorzatá KRASIŃSKA \\ Zbigniew A. KRASINSKI \& Jan M. WÓJCIK
}

\begin{abstract}
Cabon-Raczyńska K., Krasińka M., Krasiński Z. A. \& Wójcik J. M., 1987: Rhythm of daily activity and behavior of European bison in the Bialowleza Forest in the period without snow cover. Acta theriol, 32, 21: 335-372 |With 5 tables \& 6 Figs |.

In 1982-1981, the attivity of Europem bison Bisou boncsus (Linnaeus, 1758) was observed continuously from dawn to dusk. It heis been found that the rhythm of activity consists of many phases. The feeding, resting, and . W. 1 king activities of sicup members are highly synhronized, implying that the group is a highly consolidated structural unit of bison populations. Europer $n$ bison allocate $60.4^{0} \%$ of the day for foraging, $31.9 \%$ for resting, and $7.7 \%$ for movements without foraging. The foraging time is used for grazing in $95.2 \%$ on the average, browsing in $2.9 \%$, and barking in $1.9 \%$. Young calves suck their mothers several times a day for $4.2 \pm 1.3 \mathrm{~min}$ in the period May-July. Older calves draw milk significantly longer from August to October, that is, $6.7 \pm 3.4 \mathrm{~min}$ on the average. Wallowing was more frequent in adults than in young animals, and among adults more frequent in cows than in bulls in which it was intensified during the rutting period.
\end{abstract}

[Mammals Res. Inst., Polish Acad. Sci., 17-230 Bialowieża (KCR, MK, JMW) and Bialowieża National Park (ZAK), 17-230 Bialowieża, Poland]

\section{INTRUDUCTION}

European bison -ison bonasus (Limnaeus, 1758) are free ranging in the Bialowieza Forest, thus it was possible to study their ecology in the natural habitat (Krasinski, 1978, 1978a). In 1976--1981, the behavior of European bison was investigated in winter periods, when these animals are aggregated at sites with additional food supplied in winter (Caboń-Raczyniska et al., 1983).

In the period without snow cover, European bison have good foraging conditions in the Białowieza Forest. Due to this, from spring (that is, from snow melting) to late autumn (usually until the permanent snow cover) bison live without much disturbance from man and rather is accordance with the ecology and biology of the species (Krasiniski, 1978; Krasińska et al., 1986).

Scarce studies on the behavior of bison were carried out in enclosures of the Prague ZOO (Vajner, 1980), in IJolland (Van Den Brink, 1980), 
and in the national park Bayerische Wald (Krischke, 1984). These animals were permanently supplied with food by man and their groups were artificially formed in enclosures. Only Korockina (1972) observed a free ranging herd in the Russian part of the Bialowieża Forest.

The present study is focused on the rhythm of activity of European bison in mixed groups and their behavior in the natural habitat. The observations are analysed from the point of view of both individual behavior and the behavior of groups characterized by the natural organization. This study corresponds to the problems concerning all processes of utilizing forest habitats by the European bison population in Bialowieża, which are the subject of a separate paper (Krasinska et al., 1987).

\section{MATERIAL AND METHOD}

Observations on the activity rhythm of European bison groups and the behavior of individual group members were conducted in 1982-84. A total of 20 daily cycles of observations were made from dawn to dusk. Two observers were working concurrently to increase the precision of records of individual behavior in the group, using $7 \times 50$ binoculars. Bison groups were observed in different months from April to September. The duration of different activity types of the group and individual animals were noted. The routes of movements of the group during foraging and during walking were drawn on maps of forest compartments to determine distance covered by the group during the day. Three basic forms of behavior were distinguished: 1) feeding, 2) resting (lying. and standing), and 3) movements without feeding (walking). In addition, such forms of individual behavior were recorded as playing, grooming, sexual behavior, agonistic behavior, mother-calf-relationship, and vocalisation. The duration of calf milking was noted.

Different forms of group activity are described in 15-minute intervals. The percentage of individuals in particular activity phases was noted.

The mean duration of the observation cycle of groups was $892 \pm 60.1$ min. Description of individual behavior of adults was made in part during the whole-day observations, and also diring a separate programme implemented in 1976-1984, when 2052 observations of mixed groups and 1041 observations of bull groups and single bulls were made.

The terminology used here for behavior description follows that applied by Shult (1972) for behavior of the American bison.

\section{RHYTHM OF DAILY ACTIVITY OF MIXED GROUPS}

The duration of three main activity forms for European bison groups in the period when they use natural food is shown in Table 1 . Over this period, bison used $60.4 \%$ the time, on the average, for feeding, $31.9 \%$ for resting, and $7.7 \%$ for walking. The duration of feeding in different days ranged from $46.8 \%$ to $81.6 \%$ of the daily activity (Table 1). 
Table 1

Forms of the daily activity of mixed groups of bison.

\begin{tabular}{|c|c|c|c|c|c|c|c|c|c|c|c|c|c|c|c|c|}
\hline \multirow{3}{*}{ Date } & \multicolumn{14}{|c|}{ Forms of the daily activity of mixed groups of bison } & \multirow{3}{*}{ Drinking } & \multirow{3}{*}{$\begin{array}{c}\text { Migra- } \\
\text { tion } \\
\text { dist. } \\
\text { (m) }\end{array}$} \\
\hline & \multirow{2}{*}{$\begin{array}{l}\text { Group } \\
\text { size }\end{array}$} & \multirow{2}{*}{$\begin{array}{l}\text { Time of } \\
\text { observation } \\
\text { (minutes) }\end{array}$} & \multicolumn{4}{|c|}{ Feeding, (minutes) } & \multicolumn{4}{|c|}{ Resting, (minutes) } & \multicolumn{4}{|c|}{ Walking, (minutes) } & & \\
\hline & & & & $\min$ & $\max$ & $\%$ & & $\min$ & $\max$ & $\%$ & & $\min$ & $\max$ & $\%$ & & \\
\hline 12.04 .1983 & 12 & 780 & 435 & 60 & 120 & 55.8 & 315 & 15 & 105 & 40.4 & 30 & 15 & - & 3.9 & - & 9000 \\
\hline 17.04 .1984 & 9 & 885 & 540 & 60 & 270 & 61.0 & 255 & 45 & 120 & 28.8 & 90 & 30 & 60 & 10.2 & 1 & 3800 \\
\hline 3.05 .1984 & 9 & 915 & 645 & 15 & 150 & 70.5 & 150 & 15 & 60 & 16.4 & 120 & 15 & 60 & 13.1 & 1 & 8500 \\
\hline 5.05 .1983 & 10 & 855 & 405 & 15 & 105 & 47.4 & 390 & 15 & 195 & 45.6 & 60 & 15 & - & 7.0 & - & 10000 \\
\hline 6.05 .1982 & 11 & 990 & 810 & 15 & 285 & 81.8 & 180 & 15 & 90 & 18.2 & - & - & - & - & 1 & 3250 \\
\hline 28.05 .1982 & 28 & 930 & 435 & 15 & 165 & 46,8 & 240 & 15 & 120 & 25.8 & 235 & 15 & 90 & 27.4 & 2 & 12500 \\
\hline 25.06 .1982 & 30 & 1035 & 600 & 45 & 210 & 58.0 & 150 & 15 & 90 & 14.5 & 285 & 15 & 180 & 27.5 & 1 & 16000 \\
\hline 28.06 .1983 & 11 & 870 & 510 & 120 & 210 & 58.6 & 360 & 15 & 105 & 41.4 & - & - & - & - & - & 3500 \\
\hline 5.07 .1984 & 27 & 855 & 465 & 45 & 195 & 54.4 & 375 & 60 & 180 & 43.8 & 15 & - & - & 1.8 & - & 2000 \\
\hline 12.07 .1984 & 40 & 900 & 435 & 90 & 180 & 48.3 & 390 & 15 & 255 & 43.3 & 75 & 30 & 45 & 8.4 & 1 & 6000 \\
\hline 13.07 .1982 & 23 & 945 & 660 & 15 & 300 & 69.8 & 150 & 15 & 135 & 15.9 & 135 & 15 & 60 & 14.3 & 1 & 17500 \\
\hline 20.07 .1982 & 10 & 960 & 585 & 15 & 315 & 60.9 & 300 & 45 & 180 & 31,3 & 75 & 15 & 60 & 7.8 & 1 & 14500 \\
\hline 24.07 .1984 & 14 & 885 & 525 & 45 & 210 & 59.3 & 345 & 60 & 180 & 39.0 & 15 & - & - & 1.7 & - & 3500 \\
\hline 27.07 .1982 & 19 & 870 & 495 & 15 & 120 & 56.9 & 270 & 15 & 90 & 31.0 & 105 & 15 & 45 & 12.1 & - & 9000 \\
\hline 1.08 .1984 & 30 & 870 & 480 & 45 & 165 & 55.2 & 375 & 45 & 195 & 43.1 & 15 & - & - & 1.7 & - & 6000 \\
\hline 18.08 .1983 & 10 & 855 & 480 & 30 & 180 & 56.1 & 375 & 15 & 165 & 43.8 & - & - & 一 & - & - & 2300 \\
\hline 24.08 .1984 & 11 & 885 & 525 & 15 & 135 & $59.3^{\circ}$ & 345 & 15 & 135 & 39.0 & 15 & - & - & 1.7 & - & 4500 \\
\hline 28.08 .1984 & 24 & 870 & 645 & 75 & 210 & 74.1 & 225 & 45 & 90 & 25.9 & - & - & - & - & 1 & 4500 \\
\hline $11,09,1984$ & 16 & 810 & 600 & 90 & 255 & 74.1 & 150 & 60 & 90 & 18.5 & 60 & 15 & 30 & 7.4 & - & 5000 \\
\hline Average & & $\begin{array}{r}892.9 \\
\pm 60.1\end{array}$ & $\begin{array}{r}540.8 \\
\pm 101.7\end{array}$ & & & 60.4 & $\begin{array}{r}281.0 \\
\pm 91.5\end{array}$ & & & 31.9 & $\begin{array}{r}90.0 \\
\pm 83.1\end{array}$ & & & 7.7 & & $\begin{array}{r}7471.0 \\
\pm 4723.1\end{array}$ \\
\hline
\end{tabular}


The duration of resting is closely related to rumination. But the latter was not recorded for individual bison because of the difficulty in measuring it. Resting (lying and standing) was also variable, ranging from 14.5 to $45.6^{\mathrm{W}} \mathrm{m}$ of the daily activity tine. In one case, excluded from the tables, which took place on 6 June, 1979 , a group of 48 individuals did not forage from 7.00 to 18.00 , and all this time it was resting on a sandy opening (Fig. 1). The reason for this unusual behavior could have been extreme weather conditions (prolonged drought and heat).

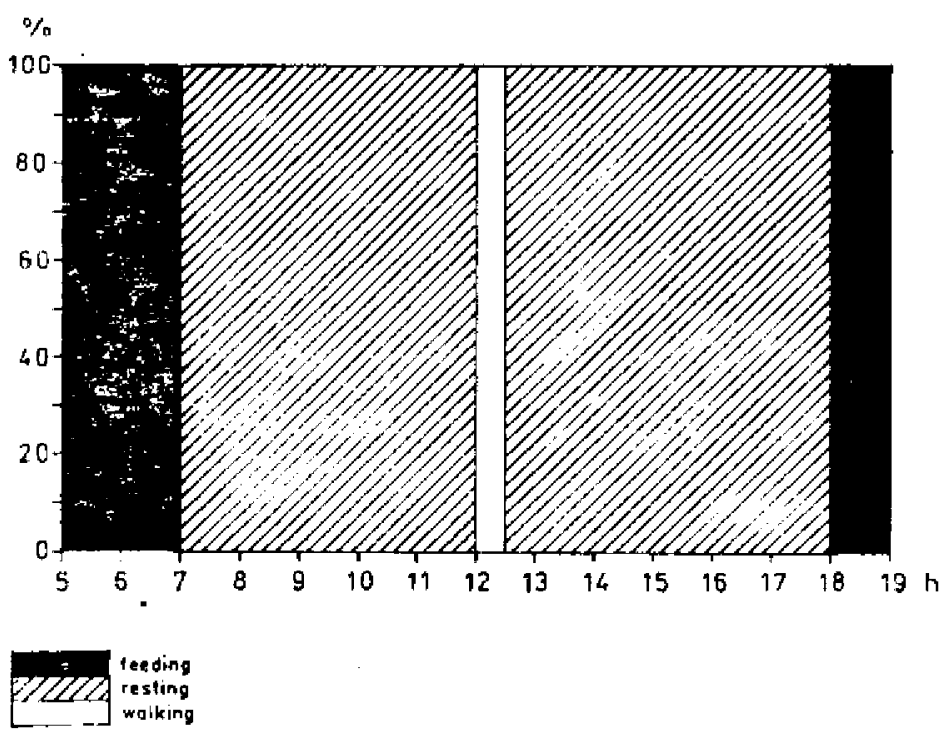

Fig. 1. Activity rhythm of one mixed group. June $6,1979, n=48$.

Our observations shows that walking occurs when bison move from one feeding sile to another, go to watering places, or search for resting sites. The time allocated for walking can account for up to $27 \%$ of the total daily activity. During four daily observations, no movements without feeding were observed.

The feeding activity of mixed groups is of a polyplase character: the phase of feeding is interspersed with shorter or longer periods of resting or walking. Feeding occurred at any time of the day. Most groups were feeding early in the morning and prior to sunset, but not clear cyclicity was found (Fig. 2). However, when the results of 19 observations were pooled (Fig. 3), four periods of feeding activity can be distinguished: one after the sunrise, two peaks in the middle of the day, and the fourth prior to sunset. Numerous observations of groups and individual animals in different times of the year dicl not reveal other periods of feeding 


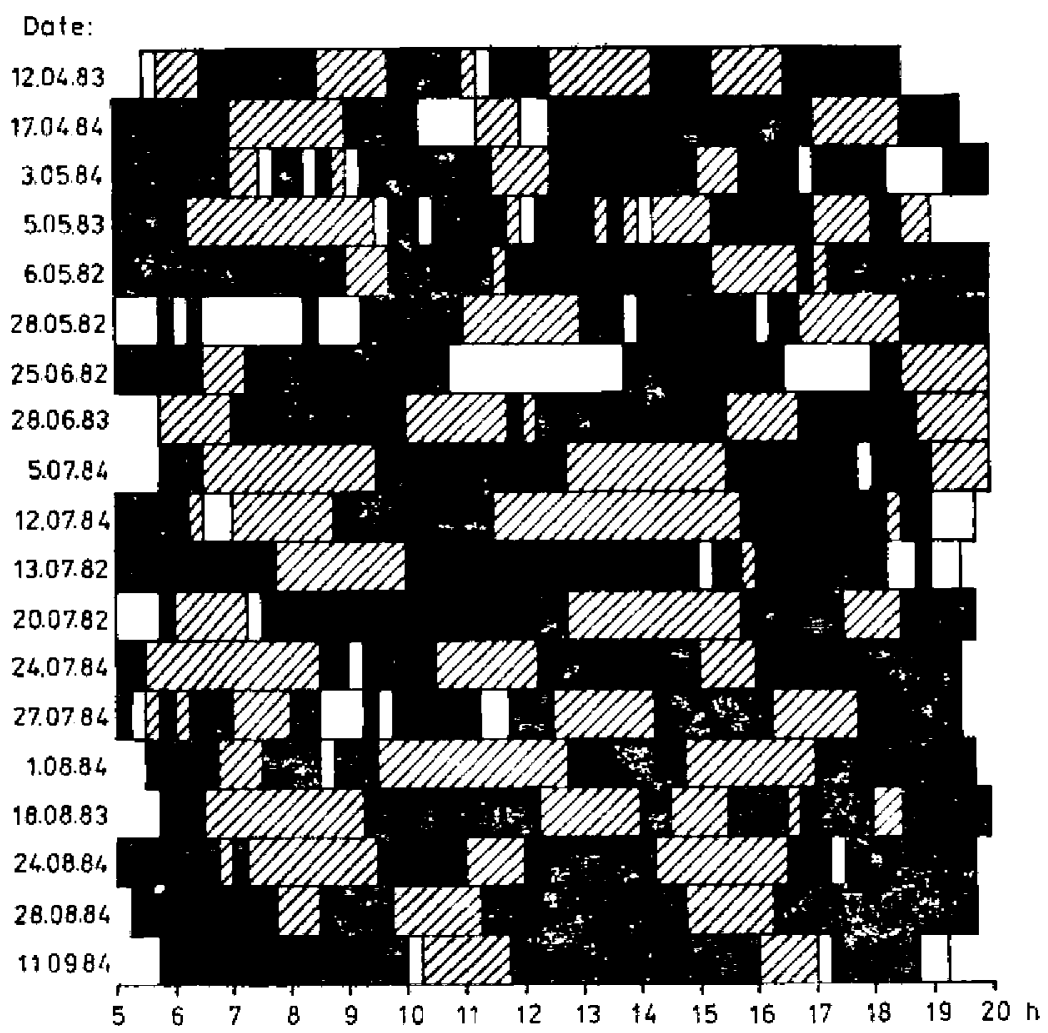

Fig. 2. Dally activity rhythms of all mixed groups observerl in the period without snow cover. Symbols as in Fig. 1.

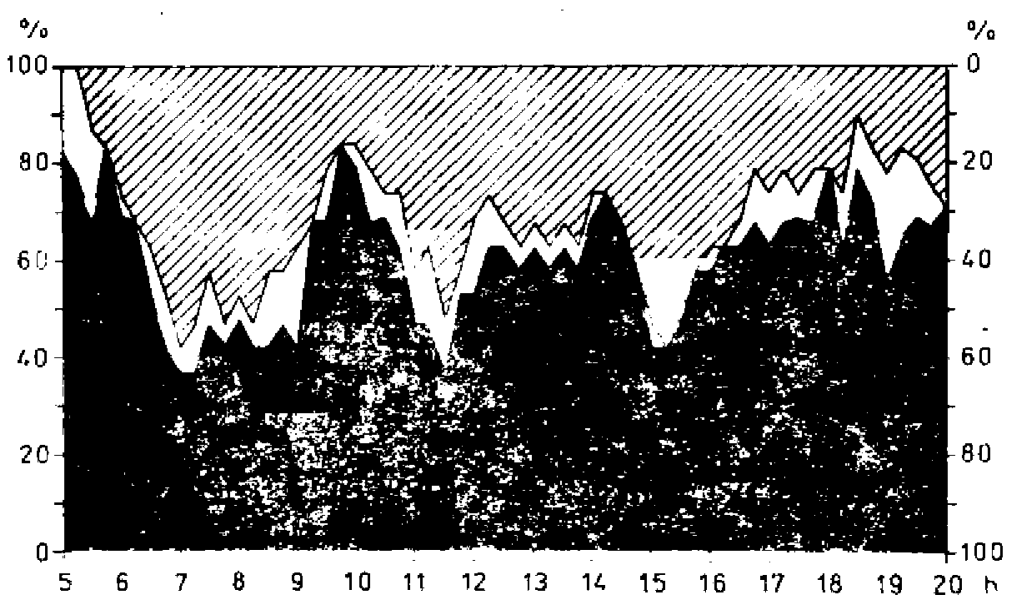

Fig. 3. Average daily activity rhythm of mixed groups in the period without snow cover. Symbols as in Fig. 1. 
A. April 12, 1984; $n=12$

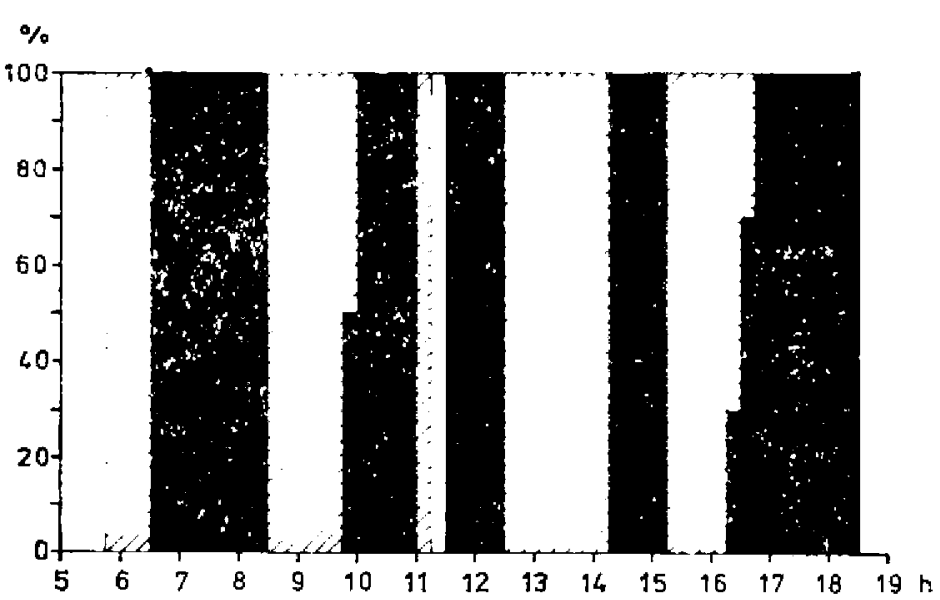

C. June 28,$1983 ; n=11$

$$
\%
$$

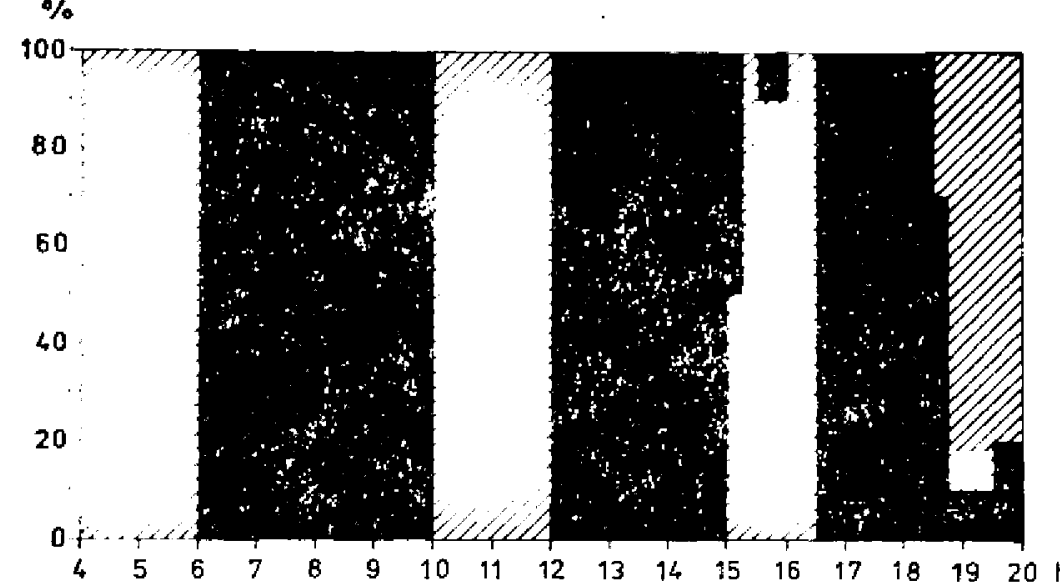

B. May 3, 1984; $n=15$

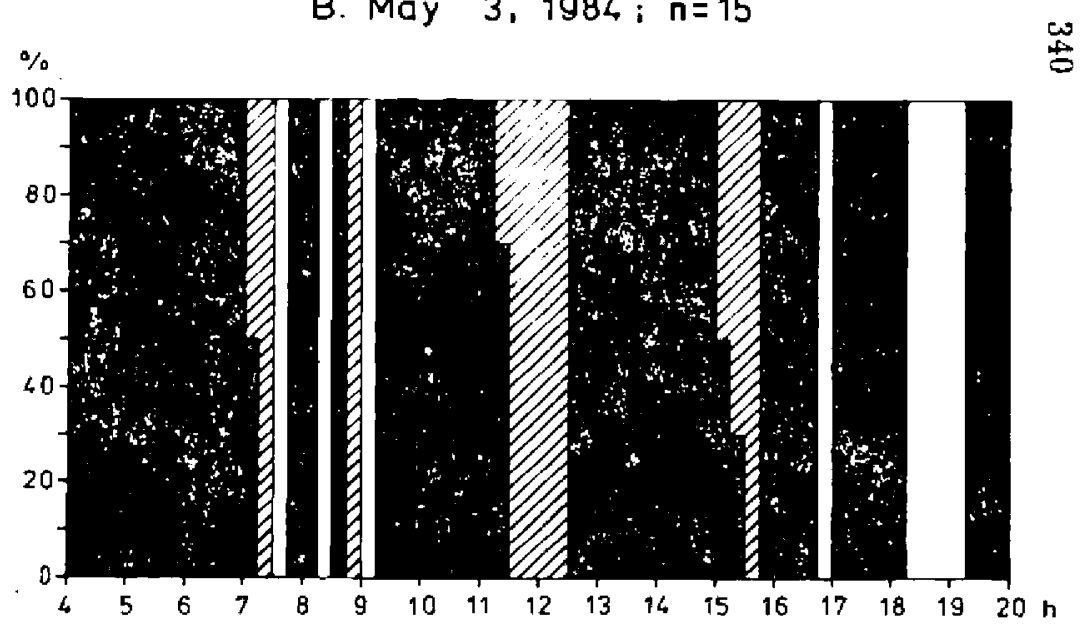

D. July 5,$1984 ; n=27$

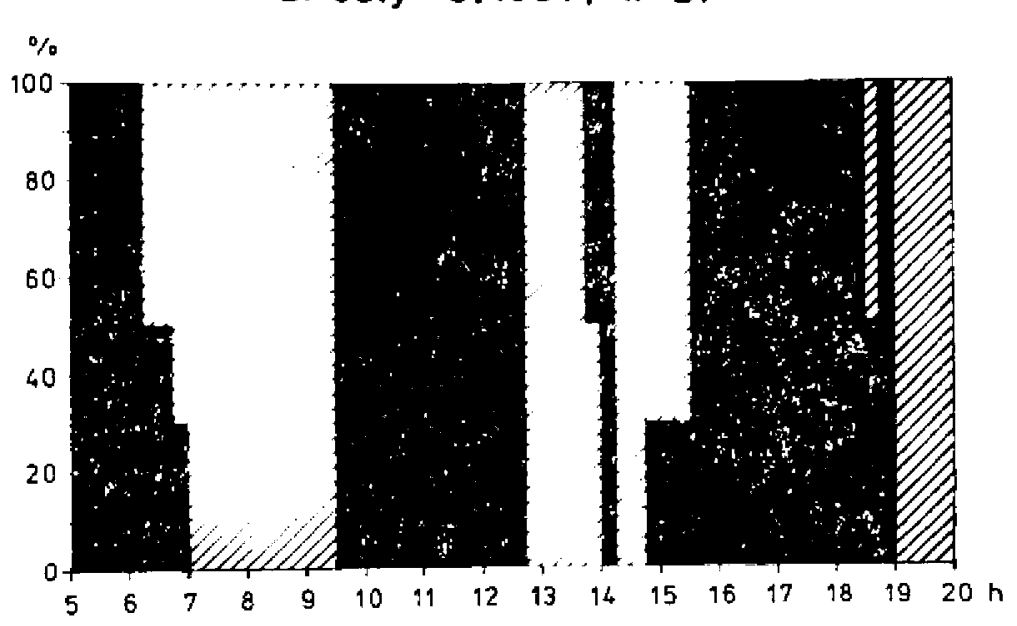


F. August 24,$1984 ; n=11$

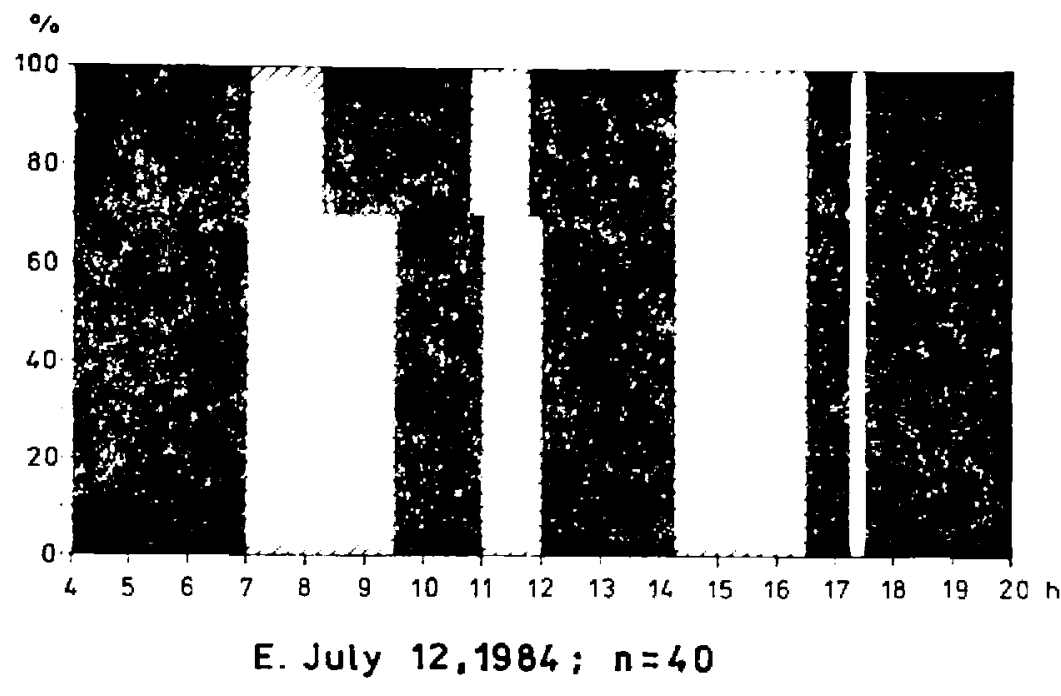

$\%$

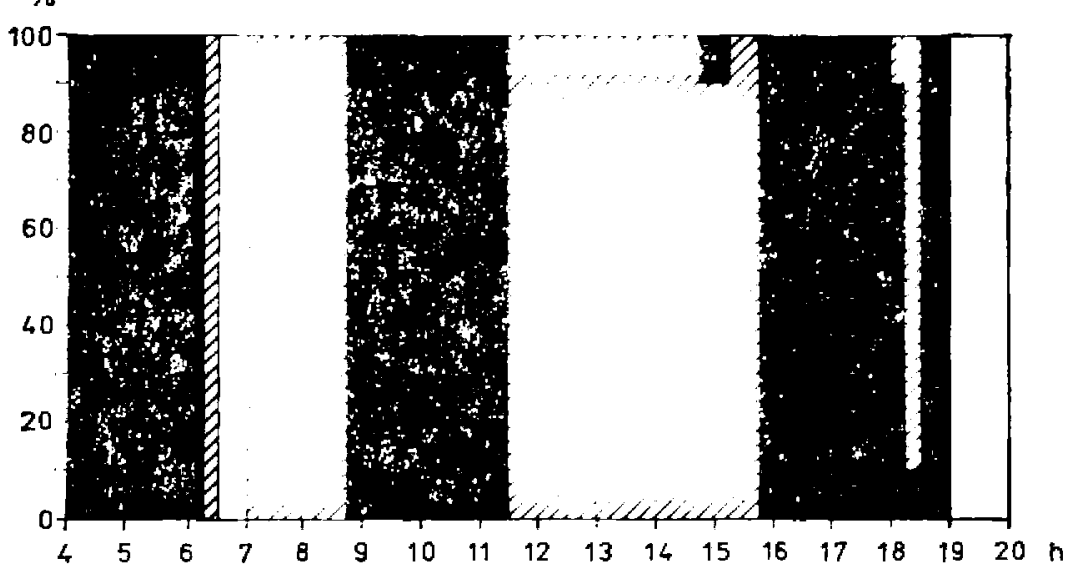

G. September 11,$1984 ; n=16$

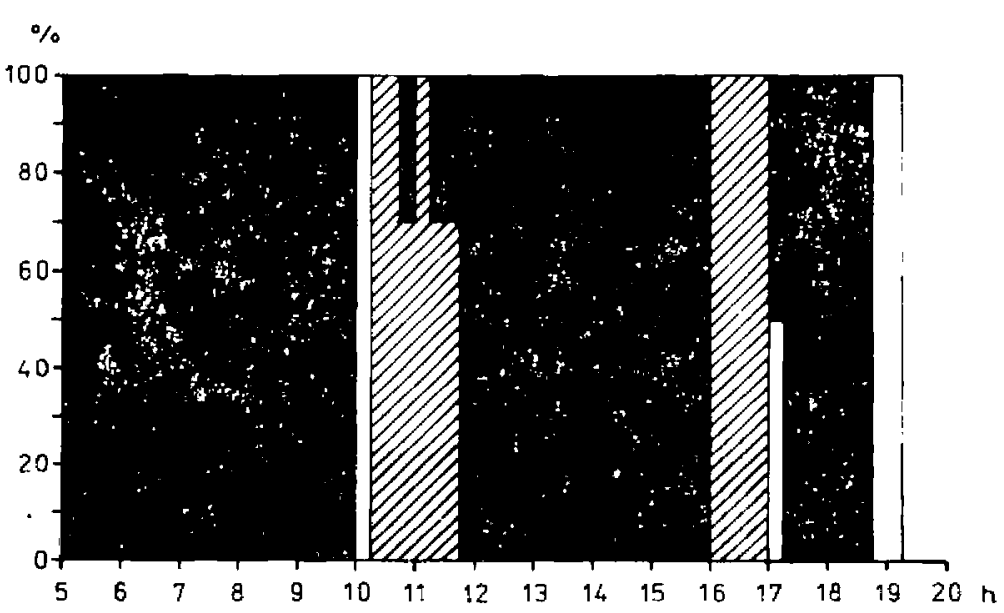

Fig. 4. Typical examples of the daily activity rhythm of different mixed groups of the European bison. Dates of observation and group size $(n)$ are indicated. 
activity than these four. The low distinctiveness of the feeding cycles during the day may be due to the fact that they depend on many environmental and behavioral factors. These factors involve variable weather conditions, abundance of noxious insects, food resources, or casual disturbance by man. Our observations of a mixed group early in the morning of the day following the day of the whole-day observation, have shown that at night the group is resting. In 15 out of 19 complete daily cycles, in the early morning the group was found close to the place of the evening resting on the preceding day $(100-300 \mathrm{~m})$.

The duration of a single feeding bout largely varied from 15 minutes to $5 \mathrm{~h} 15^{\prime}$. The corresponding data for resting ranged from $15^{\prime}$ to $4 \mathrm{hl}^{\prime} 15^{\prime}$ (Table 1). The daily rhythm of activity largely varied within a month and between months. For example, short 1-2-hour feeding periods were interspersed with equally short periods of resting in April, at the begimning of the growing season (Fig. 4A). In May of 1984, feeding bouts were long, lasting 2--3 hours, and they were interspersed with short resting and walking bouts. In June of 1983 (Fig. 4C) there were long, 3 -4-hour feeding periods and shorter, 1-2-hour resting periods. In September of 1984 (Fig. 4G), there were two very long feeding bouts (of 4 and $5 \mathrm{~h}$ ) and two short walking bouts. The observed diversity of the duration of different activity types implies that bison have no stable, regular rhythm of daily activity.

The length of the daily routes of mixed groups in the Bialowieza Forest is the sum of movements without feeding (walking) and the distance covered during foraging. It is highly variable, ranging from $2 \mathrm{~km}$ to $17 \mathrm{~km}$, the extreme values being noted in July (Table 1). It seems that the mobility of mixed groups is not related to their size, but a number of factors are involved here. The mean distance covered by a mixed group during the day was $7410 \pm 4723 \mathrm{~m}$ (Table 1 ).

For the group as a structural unit of the population, accordance in the activity of its members and synchronization are important. All forms of group activity showed a high degree of accordance (Fig. $4 \mathrm{~A}-\mathrm{G}$ ). In no case the activity of group members followed two different pathways, that is, in no case a part of animals were resting and a part were focding throughout the duration of a given activity type. Synchronization of group members was typically achieved over 15-ninute observation units, but often a much shorter time was needed (e.g. 5 minutes) for transition of all animals from resting to feeding. It also happened that some individuals were delayed 45 minutes when switching from feeding to resting, but during that time they remained close to the resting group. The transition from one form of activity to another does not seem to be initiated by specific group members. Only the start of walking is usually 
initiated by the leading cow. However, a case was clearly observed when the leading cow actively initiated feeding of the group after the resting period by driving away the cow lying in vicinity. This was a signal for the whole group to stand up and start feeding.

Other forms of activity such as grooming, sucking the calves, playing, etc. are individual activities and take place at different times in various individuals. For example, grooming can be performed during feeding of the group or during resting, sometimes immediately after or prior to resting. In no case all the group members were grooming concurrently. Sucking also took place at different times. Only in one out of 95 observations four cows milked their calves concurrently.

Table 2

Duration of different forms of the daily activity of selected members of a mixed group (in minutes)

\begin{tabular}{|c|c|c|c|c|c|c|c|}
\hline & & \multicolumn{6}{|c|}{ Individual symbols (numbers) } \\
\hline & & $\mathrm{UR}$ & $\mathrm{BA}$ & $\mathrm{BA}$ & No. 19 & BN & No. 10 \\
\hline \multirow{2}{*}{$\begin{array}{l}\text { Age, yrs. } \\
\text { Sex } \\
\text { Date }\end{array}$} & & $\frac{11}{F}$ & $\begin{array}{c}13 \\
F\end{array}$ & $\begin{array}{l}13 \\
\mathbf{F}\end{array}$ & $\begin{array}{l}7 \\
M\end{array}$ & $\stackrel{B}{M}$ & $\stackrel{8}{F}$ \\
\hline & & $\begin{array}{l}\text { May 9, J } \\
1982\end{array}$ & $\begin{array}{c}\text { June } 28 \\
1983\end{array}$ & $\begin{array}{c}\text { August 18, } \\
1983\end{array}$ & $\underset{1084}{\text { August } 20,}$ & $\begin{array}{c}\text { August 24, } \\
\text { I984 }\end{array}$ & $\begin{array}{c}\text { August 28, } \\
1904\end{array}$ \\
\hline \multirow{2}{*}{$\begin{array}{l}\text { Activities: } \\
\text { Feeding }\end{array}$} & $\min$ & 726.5 & 564 & 400 & 415 & 260 & 5.25 \\
\hline & 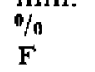 & $\begin{array}{c}74.0 \\
0\end{array}$ & 64.8 & $\begin{array}{c}57.3 \\
6\end{array}$ & $\begin{array}{l}47.7 \\
11\end{array}$ & $\begin{array}{c}34.4 \\
7\end{array}$ & 61.5 \\
\hline Resting & $\min _{0 / 0}$ & $\begin{array}{l}189 \\
20.0 \\
5\end{array}$ & $\begin{array}{l}290 \\
33.3\end{array}$ & $\begin{array}{l}320 \\
38.6 \\
4\end{array}$ & $\begin{array}{c}125 \\
14.4\end{array}$ & $\begin{array}{c}400 \\
53.0 \\
5\end{array}$ & $\begin{array}{c}200 \\
23.0 \\
7\end{array}$ \\
\hline \multirow[t]{2}{*}{ Grooming } & $\min _{\%}$ & $\begin{array}{r}56 \\
5\end{array}$ & $\begin{array}{l}10 \\
12\end{array}$ & $\begin{array}{l}25 \\
2.9\end{array}$ & $\begin{array}{l}0 \\
0\end{array}$ & $\begin{array}{l}0 \\
0\end{array}$ & $\begin{array}{l}0 \\
0\end{array}$ \\
\hline & $\mathbf{F}$ & $1 \times \mathrm{A}, 1 \times \mathrm{B}$ & $\mathrm{B} 1 \times \mathrm{A}$ & $1 \times A, 1 \times B$ & 0 & 0 & 10 \\
\hline \multirow[t]{3}{*}{ Drinking } & $\min$ & 5 & 0 & 0 & 10 & 0 & 0 \\
\hline & $0 / n$ & 0.5 & 0 & 0 & 1.1 & 0 & 1.1 \\
\hline & $F$ & 1 & 0 & 0 & 1 & 0 & I \\
\hline \multirow[t]{2}{*}{ Wallowing } & min. & 0 & 0 & 0 & 0 & 15 & 0 \\
\hline & $7 / 0$ & 0 & 0 & 0 & 0 & 2 & 0 \\
\hline \multirow{3}{*}{ Calf-cow rel. } & $\min$ & 3 & 0 & 15 & & & 0 \\
\hline & $0 \%$ & 0,5 & 0 & 1.2 & & & 0 \\
\hline & $F$ & jo & 0 & 2 & & & 0 \\
\hline Sexual & min. & 0 & 0 & 0 & 320 & 80 & 125 \\
\hline \multirow[t]{2}{*}{ behavior } & $\pi / 0$ & 0 & 0 & 0 & 36.8 & 10.6 & 14.4 \\
\hline & $\mathbf{F}$ & 0 & 0 & 0 & C & $\mathbf{5}$ & 9 \\
\hline $\begin{array}{l}\text { Eliminative } \\
\text { behavior }\end{array}$ & $\mathbf{F}$ & $U_{1}$ & U 1 & U1 D 1 & 0 & 0 & 0 \\
\hline $\begin{array}{l}\text { Time of } \\
\text { observation }\end{array}$ & $100 \%$ & 978 & 870 & 855 & 870 & 755 & 870 \\
\hline
\end{tabular}

Abb.: A - rubbing. B - wallowing, $C-$ sexual behavior including $4 \times$ wallowing, $3 \times$ pawing the ground with the forefeet, $4 \times$ chasing other bulls, $3 \times$ breaking branches and rubbing, $U$ - urination, $D-$ defecation, $F$ - number of activity bouts per day. 


\section{RHYTHM OF INDIVIDUAL ACTIVITY}

During the observations of the daily activity rhythm of mixed groups, also the activity of six adults of the two sexes was recorded. These individual observations were used to compare individual behavior (Table 2) with the activity rhythm of the group (Table 1). Two types of behavior can be distinguished here: 1) individuals changing their activity in accordance with the actiyity rhythm of the group and 2) individuals following their own rhythms, not in accordance with the group activity. The first group comparised two cows, one of which was observed twice. The second group consisted of a cow in the rutting period and sexually active bulls.

In three cows representing the first type of group behavior some individual activities were performed independent of the group behavior. For example, grooming took from 1 to $5^{\text {m }}$ of the day and was performed during feeding and/or resting of the group. This behavior comprised wallowing $1-3$ times a day and rubbing 5 times. For milking and taking care of the calves, cows allocated $0.5-1.2 \%$ of their daily activity. Urination in cows occurred $1-3$ times a day and defecation once a day. Ilowever, observations were started some after the group finished its night resting after which they are likely to defecate, too.

The second type of behavior was demonstrated by two bulls attending a cow in the rutting period and by a cow showing signs of rutting, one day before mating. The feeding lime of the cow was shorter by $20 \%$ than the feeding time of the group (Tables 1 and 2), and she displayed sexual activity with the accompanying bull for $14 \%$ of the time. In this case, the time of sexual behavior of the cow depended on the behavior of the bull (courting, licking, attempts to draw of the cow from the group). The following differences were observed in the duration of various behavior types between two bulls in the rutting period, members of a mixed group, and the rest of the group: feeding time shorter by 26 and $27 \%$, and resting time shorter by $12 \%$ than those of the group. The second bull was resting by $14 \%$ longer than the group, but this was related to a fight with another bull. Sexual behavior of the bulls took $10.6 \%$ and $38^{\mathrm{H}} \mathrm{\%}$ of the day. In the first case, this time involved a $30-\mathrm{mi}-$ nute fight with another bull, who wanted to join group and was defeated, and in the second case such forms of rutting behavior were involved as wallowing ( 4 times per observation), chasing of other bulls from the cow (4 times), pawing the ground with the fore feet (3 times), breaking branches ( 4 times), and attempts to mount a cow (3 times). The duration of sexual behavior in both sexes was variable and dependent on the rutting phase in the cow and on the number of bulls in the mixed group.

It was not possible to investigate the total cycles of the daily activity 
of calves because they were not marked, so it was difficult to identify them, and also it was difficult to observe them in the forest.

\section{BEHAVIOR}

\subsection{Feeding Behavior in Different Forest Habitats}

Mixed group forage while moving through different types and age classes of stands and through unforested habitats (e.g. meadows in forests). Individuals feeding in the group keep a certain distance from each other, typically several metres, and they move in the direction of movement of the entire group. Calves at most several months old stay close to their mothers, older forage in the middle of the group. The leadership during feeding is not always clear. In some cases the leading cow was at the head of the group. This happened, for example, when bison crossed a path in the forest after finishing feeding. If they crossed such a border while feeding, the group moved as a whole, without noticeable leadership.

Three main types of the feeding of mixed groups can be described quantatively: feeding on the herb layer (grazing), browsing, and barking.

Grazing averaged $95.2 \%$ of the feeding time (Table 3). During the growing season, the herb layer was the main source of food, independent of the forest type and season. In April, when herbaceous plants were starting their growth, Anemone nemorosa flowers were the main components of the herb layer.

Browsing of leaves and young twigs was a rather regular but small component of the diet. On the average, browsing accounted for $2.9 \%$ of the feeding time. Browse was taken in largest arnounts in June and July, mostly in deciduous forests and mixed coniferous forests, accounting then for $11.8 \%$ of the feeding time. Thus the increased proportion of twigs in the diet occurred at the vegetation peak, when they reached the highest nutritive value (Drożdz, 1979).

Rarking was clearly seasonal. It accounted for a high proportion of the feeding time ( $\max .20 .7 \%$ ) only in spring (April), when there were no fresh twigs yet and the amount of herb layer was limited both quantitatively and qualitatively. At that time bison stayed near winter clearcuts and barked mostly trunks and branches of aspens (Populus tremula) cut down. In the other periods of the growing season, barking occurred occasionally. Only single individuals were barking at that time, and the preferred trees consisted of aspens, ashes (Fraxinus excelsior), spruces (Picea abies), lindens (Tilia cordata), hornbeams (Carpinus betulus), and occasionally hazels (Corylus avellana). During the whole study period, barking accounted for $1.9 \%$ of the feeding time, on the average. Only the 
Table 3

Feeding duration of mixed groups of bison in different forest types. The time of feeding is expressed in minutes and in percentage of time (in italics), ${ }^{*}$, denotes a single barking by a bull, not included to the total sum of barking time.

\begin{tabular}{|c|c|c|c|c|c|c|c|c|c|c|c|c|c|}
\hline \multirow{2}{*}{ Date } & \multirow[b]{2}{*}{$\min }$. & \multirow[b]{2}{*}{ MCF } & \multicolumn{2}{|c|}{ Grazing } & \multirow[b]{2}{*}{$A$} & \multicolumn{3}{|c|}{ Browsing } & \multirow[b]{2}{*}{$\mathrm{A}$} & \multicolumn{4}{|c|}{ Barking } \\
\hline & & & DF & MDF & & MCF & $\mathrm{DF}$ & $\mathrm{MDF}$ & & MCF & $\mathrm{DF}$ & $\mathrm{MDF}$ & A \\
\hline 12.04 .83 & 435 & - & $\begin{array}{l}225 \\
51.7\end{array}$ & - & $\begin{array}{l}90 \\
20.7\end{array}$ & & & & & - & $\begin{array}{l}30 \\
6.9\end{array}$ & - & $\begin{array}{l}90 \\
20.7\end{array}$ \\
\hline 17.04 .84 & 540 & - & $\begin{array}{l}90 \\
16.7\end{array}$ & - & $\begin{array}{l}390 \\
72.2\end{array}$ & & & & & - & - & - & $\begin{array}{l}60 \\
11.1\end{array}$ \\
\hline 3.05 .84 & 645 & $\begin{array}{l}435 \\
67.4\end{array}$ & $\begin{array}{l}120 \\
18.6\end{array}$ & $\begin{array}{l}90 \\
14.0\end{array}$ & - & & & & & & & & \\
\hline 5.05 .83 & 405 & $\begin{array}{r}345 \\
85.2\end{array}$ & $\begin{array}{l}30 \\
7.4\end{array}$ & $\begin{array}{l}15 \\
3.7\end{array}$ & - & $\begin{array}{l}15 \\
3.7\end{array}$ & - & - & - & & & & \\
\hline 6.05 .82 & 810 & $\begin{array}{l}810 \\
100\end{array}$ & - & - & - & & & & & & & & \\
\hline 28.05 .82 & 435 & $\begin{array}{l}315 \\
72.4\end{array}$ & $\begin{array}{l}15 \\
3.4\end{array}$ & - & $\begin{array}{l}105 \\
24.1\end{array}$ & & & & & & & & \\
\hline 25.06 .82 & 600 & $\begin{array}{l}165 \\
27.5\end{array}$ & $\begin{array}{l}195 \\
32.5\end{array}$ & - & $\begin{array}{l}210 \\
35.0\end{array}$ & - & $\begin{array}{l}30 \\
5.0\end{array}$ & - & - & & & & \\
\hline 28.06 .83 & 510 & $\begin{array}{l}210 \\
41.2\end{array}$ & - & $\begin{array}{l}195 \\
38.2\end{array}$ & - & $\begin{array}{l}60 \\
11.8\end{array}$ & - & $\begin{array}{l}45 \\
8.8\end{array}$ & - & & & & \\
\hline 5.07 .84 & 465 & $\begin{array}{l}465 \\
100\end{array}$ & - & - & - & & & & & r & & & \\
\hline 12.07 .84 & $\mathbf{4 3 5}$ & - & $\begin{array}{l}345 \\
79.3\end{array}$ & - & $\begin{array}{l}45 \\
10.3\end{array}$ & - & $\begin{array}{l}30 \\
6.9\end{array}$ & 一 & $\begin{array}{l}15 \\
3.4\end{array}$ & & * & & \\
\hline 13.07 .82 & 660 & $\begin{array}{l}180 \\
27.3\end{array}$ & $\begin{array}{l}405 \\
61.4\end{array}$ & - & $\begin{array}{l}60 \\
9.1\end{array}$ & - & $\begin{array}{l}15 \\
2.2\end{array}$ & - & - & & & & \\
\hline 20.07 .82 & 585 & $\begin{array}{l}135 \\
23.1\end{array}$ & $\begin{array}{l}240 \\
41.0\end{array}$ & $\begin{array}{l}120 \\
20.5\end{array}$ & $\begin{array}{l}75 \\
12.8\end{array}$ & $\begin{array}{l}15 \\
2.6\end{array}$ & - & - & - & & & & \\
\hline 24.07 .84 & 525 & $\begin{array}{l}480 \\
91.4\end{array}$ & - & $\begin{array}{l}45 \\
8.6\end{array}$ & - & & & & & & & & \\
\hline 27.07 .82 & 495 & $\begin{array}{l}105 \\
21.2\end{array}$ & - & $\begin{array}{l}390 \\
78.8\end{array}$ & - & & & & & & & & \\
\hline 1.08 .84 & 480 & $\begin{array}{l}30 \\
6.2\end{array}$ & $\begin{array}{l}375 \\
78.2\end{array}$ & $\begin{array}{l}30 \\
6.2\end{array}$ & $\begin{array}{l}45 \\
9.4\end{array}$ & & & & & & & & \\
\hline 18.08 .83 & 480 & - & $\begin{array}{l}390 \\
81.2\end{array}$ & $\begin{array}{l}15 \\
3.2\end{array}$ & $\begin{array}{l}30 \\
6.2\end{array}$ & - & $\begin{array}{l}45 \\
9.4\end{array}$ & - & - & & & & \\
\hline
\end{tabular}




\begin{tabular}{|c|c|c|c|c|c|c|c|c|c|c|c|c|c|}
\hline $\begin{array}{r}24.08 .84 \\
28.08 .84\end{array}$ & $\begin{array}{l}525 \\
645\end{array}$ & $\begin{array}{l}105 \\
20.0 \\
-\end{array}$ & $\begin{array}{l}270 \\
51.4 \\
630\end{array}$ & $\begin{array}{l}135 \\
25.7 \\
-\end{array}$ & - & & & - & $\ldots$ & $\begin{array}{l}15 \\
2.9\end{array}$ & - & - & - \\
\hline 28.08 .84 & 645 & & $\begin{array}{l}000 \\
97.5\end{array}$ & - & - & - & $\begin{array}{l}15 \\
2.3\end{array}$ & & & & & & \\
\hline 11.09 .84 & 600 & - & $\begin{array}{l}585 \\
97.5\end{array}$ & - & - & - & $\begin{array}{l}15 \\
2.5\end{array}$ & - & - & & & & \\
\hline Total, min. & 10275 & 3780 & 3915 & 1035 & 1050 & 90 & 150 & 45 & 15 & 15 & 30 & - & 150 \\
\hline $\begin{array}{l}\text { Avg. } \\
\pm \text { SD }\end{array}$ & $\begin{array}{l}540.8 \\
101.6\end{array}$ & $\begin{array}{l}198.9 \\
224.0\end{array}$ & $\begin{array}{l}206.0 \\
204.2\end{array}$ & $\begin{array}{l}54.5 \\
99.4\end{array}$ & $\begin{array}{l}55.3 \\
97,6\end{array}$ & $\begin{array}{l}4.7 \\
14.2\end{array}$ & $\begin{array}{l}7.9 \\
13.6\end{array}$ & 2.4 & 0.8 & 0.8 & 1.6 & & 7.9 \\
\hline$\%$ & 100.0 & 36.8 & 38.1 & 10.1 & 10.2 & 0.9 & 1.5 & 0.5 & 0.1 & 0.1 & 0.2 & & 1.5 \\
\hline Total, min. & & & $\begin{array}{l}514.7 \\
95.2\end{array}$ & & & & $\begin{array}{l}15.8 \\
2.9\end{array}$ & & & & $\begin{array}{l}10.3 \\
1.9\end{array}$ & & \\
\hline
\end{tabular}

Abbreviations: MCF - Mixed coniferous forest, DF - Deciduous forest, MDF - Mixed deciduous forest, A - Alderwood 
Table 4

Feeding duration of mixed groups of bison from different age classes and in stands of various forest types. The time of feeding is expressed in minutes and in percentage of time (in italics).

\begin{tabular}{|c|c|c|c|c|c|c|c|c|c|c|c|}
\hline \multirow{2}{*}{ Date } & \multirow{2}{*}{$\begin{array}{l}\text { Feeding } \\
\text { activity } \\
\text { (min.) }\end{array}$} & \multirow{2}{*}{$\frac{\text { Mixed }}{1}$} & \multirow{2}{*}{$\frac{\text { coniferous }}{2}$} & \multirow{2}{*}{$\frac{\text { forest }}{3}$} & \multicolumn{3}{|c|}{ Deciduous forest } & \multicolumn{2}{|c|}{ Mixed deciduou } & \multirow{2}{*}{$\frac{15 \text { forest }}{3}$} & \multirow{2}{*}{$\begin{array}{l}\text { Alder- } \\
\text { woods }\end{array}$} \\
\hline & & & & & 1 & 2 & 3 & 1 & 2 & & \\
\hline 17.04 .84 & 540 & - & - & - & $\begin{array}{l}01.1 \\
60 \\
11.1\end{array}$ & $\begin{array}{l}5.4 \\
30 \\
5.6\end{array}$ & -3 & - & - & - & $\begin{array}{l}450 \\
83.3\end{array}$ \\
\hline 3.05 .84 & 645 & $\begin{array}{l}375 \\
58.1\end{array}$ & $\begin{array}{l}45 \\
7.0\end{array}$ & $\begin{array}{l}15 \\
2.3\end{array}$ & $\begin{array}{l}90 \\
14.0\end{array}$ & $\begin{array}{l}30 \\
4.6\end{array}$ & - & $\begin{array}{l}90 \\
14.0\end{array}$ & $\bar{\ddots}$ & - & - \\
\hline 5.05 .83 & 405 & $\begin{array}{l}135 \\
33.3\end{array}$ & $\begin{array}{l}45 \\
11.1\end{array}$ & $\begin{array}{l}180 \\
44.4\end{array}$ & $\begin{array}{l}30 \\
7.4\end{array}$ & - & - & $\begin{array}{l}15 \\
3.7\end{array}$ & - & - & - \\
\hline 6.05 .82 & 810 & $\begin{array}{l}645 \\
79.6\end{array}$ & - & $\begin{array}{l}165 \\
20.4\end{array}$ & - & - & - & - & - & - & - \\
\hline 28.05 .82 & $\mathbf{4 3 5}$ & $\begin{array}{l}255 \\
58.6\end{array}$ & $\begin{array}{l}45 \\
10.3\end{array}$ & $\begin{array}{l}15 \\
3.4\end{array}$ & $\begin{array}{l}15 \\
3.4\end{array}$ & - & - & - & - & - & $\begin{array}{l}105 \\
24.1\end{array}$ \\
\hline 25.06.82 & 600 & - & - & $\begin{array}{l}150 \\
25.0\end{array}$ & $\begin{array}{l}195 \\
32.5\end{array}$ & $\begin{array}{l}30 \\
5.0\end{array}$ & - & - & - & - & $\begin{array}{l}225 \\
37.5\end{array}$ \\
\hline 28.06 .83 & 510 & $\begin{array}{l}270 \\
52.9\end{array}$ & - & - & - & - & - & $\begin{array}{l}240 \\
47.1\end{array}$ & - & - & - \\
\hline 5.07 .84 & 465 & $\begin{array}{l}465 \\
100\end{array}$ & - & - & - & - & 一 & - & - & - & - \\
\hline 12.07 .84 & 435 & - & - & - & $\begin{array}{l}345 \\
79.3\end{array}$ & $\begin{array}{l}15 \\
3.4\end{array}$ & $\begin{array}{l}30 \\
7.0\end{array}$ & - & - & - & $\begin{array}{l}45 \\
10.3\end{array}$ \\
\hline 13.07.82 & 660 & $\begin{array}{l}180 \\
27.3\end{array}$ & - & - & $\begin{array}{l}330 \\
50.0\end{array}$ & $\begin{array}{l}90 \\
13.6\end{array}$ & - & - & - & $\rightarrow$ & $\begin{array}{l}60 \\
9.1\end{array}$ \\
\hline 20.07 .82 & 585 & $\begin{array}{l}150 \\
25.6\end{array}$ & - & - & $\begin{array}{l}195 \\
33.3\end{array}$ & $\begin{array}{l}15 \\
2.6\end{array}$ & $\begin{array}{l}30 \\
5.2\end{array}$ & $\begin{array}{l}120 \\
20.5\end{array}$ & - & - & $\begin{array}{l}75 \\
12.8\end{array}$ \\
\hline 24.07 .84 & 525 & $\begin{array}{l}480 \\
91.4\end{array}$ & - & 一 & - & - & - & $\begin{array}{l}45 \\
8.6\end{array}$ & - & - & - \\
\hline 27.07 .84 & 495 & $\begin{array}{l}105 \\
21.2\end{array}$ & - & - & - & - & - & $\begin{array}{l}390 \\
78.8\end{array}$ & - & - & - \\
\hline 1.08 .83 & 480 & $\begin{array}{l}30 \\
6.2\end{array}$ & - & - & $\begin{array}{l}165 \\
34.5\end{array}$ & $\begin{array}{l}15 \\
3.1\end{array}$ & $\begin{array}{l}195 \\
40.6\end{array}$ & $\begin{array}{l}30 \\
6.2\end{array}$ & - & - & $\begin{array}{l}45 \\
9.4\end{array}$ \\
\hline 18.08 .84 & 480 & - & - & - & $\begin{array}{l}405 \\
84.5\end{array}$ & $\begin{array}{l}30 \\
6.2\end{array}$ & - & $\begin{array}{l}15 \\
3.1\end{array}$ & - & - & $\begin{array}{l}30 \\
6.2\end{array}$ \\
\hline
\end{tabular}




\begin{tabular}{|c|c|c|c|c|c|c|c|c|c|c|c|}
\hline 24.08 .84 & 525 & $\begin{array}{l}120 \\
22.9\end{array}$ & - & - & $\begin{array}{l}270 \\
51.5\end{array}$ & - & - & $\begin{array}{l}135 \\
25.6\end{array}$ & - & - & - \\
\hline 28.08 .84 & 645 & - & - & - & $\begin{array}{l}220 \\
34.1\end{array}$ & $\begin{array}{l}100 \\
75.5\end{array}$ & $\begin{array}{l}325 \\
50.4\end{array}$ & - & - & - & - \\
\hline 11.09 .84 & 600 & - & - & - & $\begin{array}{l}230 \\
38.3\end{array}$ & $\begin{array}{l}110 \\
18.3\end{array}$ & $\begin{array}{r}260 \\
+\quad 43.4\end{array}$ & - & - & - & - \\
\hline Total & 10275 & 3210 & 135 & 525 & 2775 & 480 & 855 & 1080 & - & - & 1215 \\
\hline $\begin{array}{l}\text { Avg. } \\
\pm \mathrm{SD}\end{array}$ & $\begin{array}{l}540.8 \\
101.6\end{array}$ & $\begin{array}{l}168.9 \\
197.0\end{array}$ & $\begin{array}{l}7.1 \\
16.8\end{array}$ & $\begin{array}{l}27.6 \\
61.5\end{array}$ & $\begin{array}{l}146.0 \\
134.9\end{array}$ & $\begin{array}{l}25.2 \\
35.4\end{array}$ & 45.0 & $\begin{array}{l}56.8 \\
1034\end{array}$ & $=$ & - & $\begin{array}{l}63.9 \\
1138\end{array}$ \\
\hline$\%$ & 100 & 31.2 & 1.3 & 5.1 & 27.0 & 4.7 & 8.3 & 10.5 & - & - & 11.8 \\
\hline
\end{tabular}

Expl. 1 - Pole-sized stand and timber stand (over 20 yrs old), 2 - Thicket, 10-20 yrs old, 3 - Clearcuts and young plantation up to $10 \mathrm{yrs}$ old 
mean value for April was high (18.5\%), and barking accounted for a high proportion of the food.

The active feeding of European bison involves a free movement of the group, the route and speed of which depend on the food requirements of the animals. In this way bison demonstrate their habitat preferences in close relation to food preferences.

Ilabitat preferences in the Białowieża Forest were described earlier (Krasińska et al., 1987) on the basis of the frequency of observation of mixed groups of bison. They can also be described on the basis of the routes of feeding movements of mixed groups. A comparison of the duration of feeding and percentage indices of the total duration of feeding in different forest types and age classes of the stand is shown in Table 4. In the first period after leaving the feeding ricks in April, bison foraged exclusively in deciduous forests and alderwoods. In these forest types the herb layer vegetation started growing the earliest (Falinska, 1973), and deciduous trees provided bark at that time (18.5\% of the feeding time was allocated for barking). In May and June, mixed coniferous forests and, to a lower extent, deciduous forests were prefered habitats. A similar situation was in July, but in August and September bison clearly preferred deciduous and mixed forests (Table 4).

Independent of the forest type, bison utilized more tree stands older than 20 years for feeding. When age classes of all the forest types were compared, it has been found that $80.6 \%$ of the feeding time was in the stands more than 20 years old, $13.4 \%$ in clearcuts, and young forest plantations and $6.0 \%$ in thickets. In the summer period (July, August), young plantations and thickets in the mixed coniferous forest were not visited by bison. But young plantations in deciduous forests in August and September were used almost to the same extent as old stands $(47.0 \%)$. This was due to the type of management in deciduous forests, where the selective cutting was applied (small clearcuts of $0.08-0.12 \mathrm{ha}$ ), and bison could alternatively forage in the timber stand and in small clearings with fresh herb layer.

\subsection{Eliminative Behavior}

Defecating bison of both sexes stop walking, rise the tail, and slightly crouch the hind legs. Urinating females adopt a similar posture. Urinating males stand up and rise the tail. Urination and defecation typically take place in animals getting up after the rest $(63 \%$ of the observations). During feeding defecation is less frequent, and only two animals (a male and a female) urinated while walking. During resting and prior to resting defecation is rare (14\% of observations).

Most frequently, adults defecated once a day, but the early-morning 
defecation after the night resting could have been missed because observations were started too late. Urination takes place $2--3$ times a day. Calves typically urinated immediately after sucking.

\subsection{Drinking}

The sources of drinking water for bison in the Białowieża Forest are natural running waters (rivers, streams) and stagnant water in depressions of the ground, marshy synclines, peatlands, artificial watering places, gravel pits, and puddles. Bison used all these water sources.

Drinking and visits to watering places were not regular events in the daily cycle of group activity. Only in 9 out of 20 days of observations bison were drinking water, and in the remaining 11 days they did not drink at all. An analysis of weather conditions is the period preceding the days of observation slows that periods without dririking usually followed rainy periods of days. On hot days, for example, bison covered larger distances to reach watering places, as it was the case on May 3 and June 6 of 1979. On hot days, bison used watering places even twice. During one observation bison came to a water body for the second time in the evening, and drinking was combined with their entering the water. European bison were more frequently drinking water in the afternoon and evening, but on hot days they visited a drinking place at noon. Many individual observations show that bisons visit watering places also before noon.

Groups typically use permanent water bodies or running waters. Only solitary bulls used casually encountered puddles.

\subsection{Mesting}

A typical resting position is lying in the physiological position on sternum. Bison rarely lie on their sides with all legs stretched, or rest shortly while standing up. During a several-hour resting, bison stood up, stretched out their bodies, and then were resting on the other side. Frequently the change of position was preceded by wallowing.

In the resting mixed groups, small calves were lying near their mothers, and older calves frequently formed a separate group. Individual members were lying at a distance of several metres from each other. Resting bison never form a compact group in which the animals can touch their neighbours. Group resting is a well synchronized form of activity of group members. The transition from activity to resting was slower than vice versa.

The location of resting sites of mixed groups was not casual. Bison had their preferred resting sites, typically on small elevations, frequently 
located on forest ways and openings, thus in places not always completely peaceful.

In the periods of a high activity of parasitic insect, bison selected places where these insects were less abundant: dense spruce thickets without understorey, or open clearcuts. On a hot day of June, 1979, a large mixed group (48 individuals) was resting on a sandy, insolated clearcut The herd was lying there from 7.00 to 18.00 with a break at noon for going to a watering place. A part of animals were lying on their sides with stretched legs, breathing hard. The open, insolated area protected them from noxious gnats.

In other cases bison rested in places where they finished feeding, after a short period of searching for a resting site.

\subsection{Walking}

This form of behavior was observed during movements of group: is search of new feeding places, movements to watering sites or when fleeing. During walking in file, the cow leading the group headed the line, and the other group members followed her at short distances one after another. Young and older calves typically were in the middle of the line, and an old bull, if present in the group, ended the line.

Walking bison did not use the existing web of forest roads, but they moved through the forest avoiding openings and clearcuts. But severalyear observations have shown that bison. use pathways made by themselves and other animals. The utilization of existing animal pathways was not casual. Two observed groups used for feeding movements or for walking the routes that can be considered as typical in recurring spatial systems. Based on 419 observations, it has been found that these typical routes were selected in $55.1 \%$ of the cases. Taking into account the fact that directions of movements in the forest are practically unlimited, this provides an evidence for a clear preference for a distinct network of pathways within the home range of a group. In cuntrast to the mixed groups, single bulls frequently used forest roads. Tracks of solitary bulls were seen many times on straight lines separating forest compartments, on a distance of $1 \mathrm{~km}$ or longer.

\subsection{Group Merging Bchaxior}

Merging of mixed groups occurred frequently in the bison population (96 observations -- see Krasińska et al., 1987). Different groups could merge even two times on the same day, and then break again with some exchange of individuals. Encounters typically occurred without changes in the behavior of individual animals (99\% of the observations), if beyond the rutting period. In such cases, the dominance structure of the group 
did not change, and the rank of individual animals was respected by the rewcomers. Throughout the study period, there was only one observation of the fight for social position in the group between two cows. In the other cases no direct conflicts were observed, and the rank of the dominant cow was presumably demonstrated by means of signals not readily noticeable by an observer.

During the rutting period, however, merging of groups was sometimes accompanied by interactions among bulls. For example, when two groups with older bulls were merging, a typical behavior of dominants was observed. When the bulls approached each other, the one which was attacking started walking round the other bull. The latter did not respond to this contention even with a slightest movement. HIe was standing in place, with his head in the resting position, without movements or turning the head after the rival. After 10 minutes of such behavior, the contested bull quietly left the group. As it was known from the whole-day observation, this bull won a fight with another bull five hours earlier. Presumably, the exhaustion after that fight accounted for his passive response in the following conflict. The bull who remained in the combined group sniffed all the newcoming cows. In other cases of merging the groups with dominant bulls, one or both of them exhibited a demostrative behavior in the form of pawing the ground with the fore feet, wallowing, or breaking young trees. Most often the stronger bull does not respond to the contention, no lighting follows, and then the weaker individual leaves the group after some time. But if the other bull did not adopt a submissive posture and showed signs of aggression, a fight was started. Typically, such situation cccurred when the two bulls were in a similar condition. Then fighting decided the dominance position of a bull and his participation in reproduction.

When rutting cows joined a group, the dominant bull responded by approaching them and sniffing in turn. Occasionally younger bulls from this group followed the dominant bulls, approaching the cows to sniff them, and then all bulls resumed their former activity (feeding or resting).

\subsection{Agonistic Behavior}

Cows, young animals and calves rarely exhibited openly aggressive behavior. In 2052 observations there were only 11 cases when cows attacked other group members (cows, young, calves). These attacks were ended by hitting the opponent with horns, typically in the rump. Once a cow treated in this way her ealf, who insistently wanted to suck her. A light of two cows was observed on July, 11, 1980, some time after the mergence of two groups. The cow marked at an age of five years 
(No. 2) was attacked during feeding by a bigger cow, who approached her and shaked her head several times. The provoked cow No. 2 stopped feeding and by a sudden attack with her horns chased the aggressor about $20 \mathrm{~m}$ in direct contact. The chased cow resumed her aggressive behavior several times, forcing cow No. 2 stop feeding and adopt a posture threatening with a new attack rather than retreating. After 15 minutes the two cows resumed feeding quietly but keeping a larger distance from each other.

Aggression in the group, in the form of attacks on subordinate group members was intensified in stressing situations. The number of interactions between animals rose in the situation of threat, for example, upon the approaching of a man, attempts to encircle them, or repeated disturbances.

More frequently observed were passive forms of aggression, when only the intention of an attack was demonstrated, but there was no direct clash. Cows demonstrated such an intention by vertical movements of the head - shaking the head (threat posture) and this sufficed that a submissed cow or young individual retreated to a safe distance.

The aggressive behavior of rutting bulls has a different meaning. The tending bull drived away from the rutting cow young bulls, which stop at a safe distance from the pair. Bulls $4-5$ years old showed at that tine an active response which was not a fight but hostling. The aggressive behavior of a tending bull against a calf occurred in the form of chasing him from the mother.

\subsection{Mother-calf Relationship}

A detailed observation of this behavior in the Białowieża Forest was difficult because of the distance between the bison group and the observers, and owing to the vegetation prolecting bison from vicw. The parturition has not been observed so far under natural conditions. On one occasion, a cow with newly born, wet calf was observed after she joined the group. The mother was carefully licking the calf, starting with head, through the thorax, to the back parts of the body, while the calf was standing up or walking slowly. The cow encouraged the calf to follow the group by pushing it with her head. More frequently calves several days old were observed in the group. Typically, they were lying while their mothers were feeding with the group. One-month-old calves moved efficiently and usually foraged near their mothers. Also during walking the youngest calves were near their mothers and older ones in the middle of the group. 
Two detailed observations of the mother-calf relationship concern the same cow. In one year, the cow "Babula" left group with her sick calf (heavily limping) and with a two-year bull, and stayed aside for seven days, until the calf recovered. In the other year, the calf of the same cow died for unknown reasons. She was seen in a small group (with two other cows one of which had a calf), extremely excited, and uttering a call characteristic of calling a calf when she was feeding. The group was staying in this place for three days, and on the third days a dead calf was found, in the first stage of decomposition. On another occasion a cow was observed uttering calls serving for communication with the calf and staying outside the group for lwo days. Her older calf, a marked one-year-old bull (she had no current year calf) joined another group in which he stayed for a longer time. After two days of searching, the cow returned to the group.

Table 5

Duration of suckling bouts (in minutes) in the period without snow cover.

\begin{tabular}{|c|c|c|c|c|}
\hline Month & No. obsv. & Avg. & SD & $\operatorname{Min}-\operatorname{Max}$ \\
\hline May & 4 & 2.7 & 0.5 & $2-3$ \\
\hline June & 5 & 4.6 & 1.7 & $2-6$ \\
\hline July & 7 & 4.H & 0.8 & $3-5.3$ \\
\hline Subtotal (May-July) & 16 & 4.2 & 1.3 & $2-6$ \\
\hline August & B & 5.7 & 1.6 & $4-3$ \\
\hline September & 4 & 7.9 & 2.5 & $5.5--10$ \\
\hline October. & 11 & 0.19 & 4.5 & +-19 \\
\hline $\begin{array}{l}\text { Subtotal } \\
\text { (August-October) }\end{array}$ & 23 & 6.7 & 3.4 & $4-19$ \\
\hline $\begin{array}{l}\text { Born in previous year } \\
\text { (April-October) }\end{array}$ & 17 & 3.7 & 1.9 & $1.5-0.5$ \\
\hline
\end{tabular}

Suckling began on the signal from the cow or the calf. These were characteristic sounds known as grunting, frequently uttered by mothers with calves foraging in a group. Upon mother's call, the calf came immediately and started sucking, often striking the udder with the head. When sucking, young calves were standing at the sides of their mothers, paralleling them, and vigorously switched their tails. When the mother tried to walk, the calf was heading her off, and when she stopped, it resumed sucking on the other side or from the back. Older calves, born the period from May to July were sucking in short bouts of 2-6 minutes, $4.2 \pm 1.3 \mathrm{~min}$ on the average, and presumably were suckled several times a day. Older current-year calves in the period from August to Cctober were suckled longer, from 4 to 19 minutes each time, $6.7 \pm 3.4$ 
min on the average (Table 5). A three-month-old calf of the marked leading cow was suckled two times a day. Differences in the duration of suckling between the youngest calves in summer and several-monthold calves in autumn were statistically significant at $0.01<p<0.005$ (Student $t$-test). Calves were also suckled in their second year if the cow had no new offspring. This was observed even until October, but more often only in spring. The duration of suckling in this group varied from 1.5 to $6.5 \mathrm{~min}$ with an average of $3.7 \pm 1.9 \mathrm{~min}$ (Table 5). During one whole-day observation a cow suckled such a calf one time. During suckling the cow stopped feeding and resting. When the cow avoided suckling, she was fleeing, pushed the calf away with her head, or even she gave it a gentle kick when it approached from the back. These events typically occurred during the rutting period, when the cow stop milking and for some time looses interest in the calf. At that time, the calf was also chased by the tending bull.

The mother cared for the calf by licking it carefully. This frequently happened during suckling and after defecation, especially in the first month of life. On one occasion licking was continued two times for five minutes with a short break.

\subsection{Playing Behavior}

Playing behavior was typically observed in calves and juveniles, rarely in adults. In the observed bison groups, playing of the young was noted 1-2 times per day, and not all young animals in the group were involved. Calves were playing most often when the group entered an open space, like a forest opening, clearcut, or forest road. Calves were running with rised tails, jumping on hind legs, sometimes circling round. A several-day-old calf, who entered a young forest with its mother, was repeatedly jumping and tossing the rear. Young bulls simulated fights when playing, pushing each other with horns and jumping on each other. Such a play could be continued up to half an hour. Playing was initiated during feeding and during resting of the group. Two-three pairs of young bulls could be involved concurently.

\subsection{Grooming Aetivity}

This group of behaviors comprises rubbing, licking, tail switching, and wallowing.

Rubbing and licking belong to cosmetic activities, occurring with a similar frequency in bison of different sexes and ages. These activities are individually performed, although rubbing was observed in several group members concurrently. For rubbing bison use the roots of wind fallen trees, bended trees, butts of trees etc. Sometimes they scratch 
the skin with hoofs of hind limbs. These activites are typically performed prior to or after resting, or during resting (52\% of observations jointly), and also during foraging of the group (48\% of observations). Rubbing was described in detail for winter observations (Cabon-Raczynska et al., 1983). It can take from 1 to 25 minutes several times a day. The maximum duration of grooming in a cow was 1 hour. Rubbing was most frequent in summer during invasions of noxious insects, and during moulting in spring, when it facilitates the shedding of fragments of the coat.

Licking occurs in similar circumstances as rubbing. Bison can lick their bodies when lying on the ground and resting, but after a while they were standing up and continued licking and rubbing in the standing posture.

Tail switching. Keeping the insects away by switching the tail is common in grazing animals. In other cases, movements of the tail are reflexive, like in calves during suckling, or they are components of aggressive behavior, like in excited bulls during the rutting period.

Wallowing. It was rarely observed in calves (2.8\% of the observations) and juveniles (14.6"1). For adult bulls, wallowing accounted for 26.1\% of the observations and for adult cows for $56.5 \%$. Wallowing of bulls in rut was accompanied by sexual behavior. $72.7 \%$ of the observations of wallowing in bulls comes from the period from the end of July to October. In groups comprising several adult bulls the frequency of wallowing increased, and the dominant bull exhibited this activity most often. The wallowing activity of subordinate bulls was increasing in the presence of a cow in rut.

The leading cow was wallowing more frequently than the other cows. The wallowing of cows and juveniles typically occurred when the group was resting. Frequently several individuals were wallowing concurrently, or sequentially within some time. The preferred wallowing sites included sandy hills, gravelled or sandy ways and roadsides, bare ground on clearcuts or in gravel pits. These are the so-called wallows. Prior to wallowing, the bull pawed the ground with fore feet, showered himself with sand or earth, occasionally urinated in this place, and then was wallowing with his limbs stretched up. Wallowing does not involve turing over the back, thus the bison has to stand up and lie down again in order to wallow on the other side.

In 6 cases out of 253 observations of wallowing, this behavior was synchronized for most of the adult group members. Two times (on 1 May, 1978 and 23 May, 1978) a similar situation was noted, when cows descended in turn a sandy pit on a clearcut, and were wallowing on the sandy slope of the pit. 


\subsection{Sexual Behavior}

Sexual behavior was demonstrated mainly in the rutting period, that is, from late July to October ( $90 \%$ of the observations). In the pre-rutting period, reproductively active bulls ( $7-11$ years old) were rarely present in a group. In the period from April to about $20 \mathrm{July}$, only $10 \%$ of the total observations of sexual behavior of bulls was noted. It was limited to sniffing external sexual organs of cows and to adopting the lip posture. Young bulls ( $3-4$ years old) occasionally mounted a cow or each other.

Since the third ten-day period of July, reproductively active bulls joined mixed groups. Smaller groups made up of $10-12$ individuals included usually one adult bull more than 6 years old and $1-3$ bulls 4- 6 years old which did not take part in reproduction.

In large groups there could be more than one adult bull. This fact influenced the intensity of sexual behavior of bulls in the rutting period.

Sexual structure of the group in the rutting period precluded the reproduction of some bulls potentially capable of breeding, and they stayed for some time beyond the mixed groups. Frequently they followed the group, sniffing tracks of its members. They demonstrated their excitment by approaching 2-3-m high spruces, bending them, breaking, sometimes uprooting them with their horns, rubbing themselves against broken branches, and also breaking hazel thickets with hoofs and horns. In places suitable for wallowing they were pawing the ground, urinating, and wallowing with violent spreading of the legs. A bull was observed wallowing on fresh tracks of the group left on a forest way.

Young bulls present in the mixed group avoided direct contacts with the dominant bull. They interacted, however, among themselves by clashing with horns and pushing each other. They also demonstrated their force and excitement by wallowing, pawing the ground, and mounting each other. They were walking near the cow in rut but at a safe distance from the dominant bull.

When a group is approached by a bull in condition similar to that of the dominant bull, they may fight. In the rutting period, fights were observed in only 11\% of the cases of the sexual behavior of bulls in the mixed groups. The duration of a fight usually did not exceed $15 \mathrm{~min}$, and together with the period preceding the direct aggression no nore than half an hour.

Continuous observations made it possible to describe the behavior of cows in rut and bulls prior to mating. In the presence of a cow in rut, the tending bull approached her and started the so-called "courtship". The bull isolated the cow from the group, keeping her at the periphery of the group and accompanying her permanently, without eating and resting 
much. Such a pair developed the tending bond. The same bull was attending the cow until they mated. Young bulls observed the tending bond, but being subordinate they did not participate in mating. They approached the cow during inattention moments or a short resting of the tending bull. Subordinate bulls attempted to mount the cow when the tending bull was breaking shrubs or wallowing. Typically, the cominant bull was controlling the situation, and responded with shaking his head and grunting when subordinate males tried to approach the cow. Only three times during two successive days a rutting cow and a bull attending her were observed. During the first day, a series of behaviors described by Krasinski and Raczyński (1967) was observed, which can be considered as courtship. On the second day, mating was observed. Over 30 min the bull mounted the cow eight times and copulation occured. This was combined with other sexual behavior and a series of "half-mountings".

In the rutting period, fights between two bulls were observed. A total of seven fights were observed. One of them is described below to give an cxample.

On 21 August, 1984, a group of 11 individual was observed, comprising 5 cows, one young heifer, one bull 8 years old, and four calves. In the morning (5.00--9.50) no sexual behavior occurred in the group. After a resting period, the bull approached one of the cows and started licking her, then he demonstrated a typical sexual behavior: pawing the ground with fore feets, breaking branches, rubbing, loud grunting and snorting. Ile started to courtship the cow and the pair moved to the edge of the group. At 12.15 another 8-year-old bull (marked No. 23), of the size of the tending bull, joined the group trotting. He approached one of the cows, and, after sniffing her, displayed the lip curl posture, then approached the tending bull and circled him. Then, the two rivals were standing close to each other and in parallel, facing opposite directions with the heads at the height of the opponent's rump (Fig. 5A). This preparatory posture before the fight lasted for about 10 minutes, during which the two bulls several times changed their position so that they were facing each other and pushing shortly with their horns. Each rising of the head by one bull was immediately followed by the frontal position of the other bull. In the next phase the bulls were standing in parallel with the heads at the shoulder of the opponent (Fig. 5B). For about 5 minutes of this phase they stroke several times the nape or the head of the opponent with the horns or the head. Then the main phase of the fight extended for 15 minutes. The bulls were facing each other all the time (Fig. 5C, D) and repeatedly attacked each other, that is, they were holding their heads ligh! logether and strongly pushing the 
opponent with their whole bodies, also striking each other with horns. When pressing against each other, the bulls werc hooking with their horns, then they released horns and stroke the opponent's hcad with then or with the lorehead. The fighting bulls made violant turns round themselves, leaving conspicuous traces on the ground. The fight required a great effort and the animals were getting tired. They were uttering harsh calls while snorting and were changing the rate of attacks. During fighting, one of the symptoms of excitment was a rapid switching of the tail. A strong smell was left by the animals in the place of the

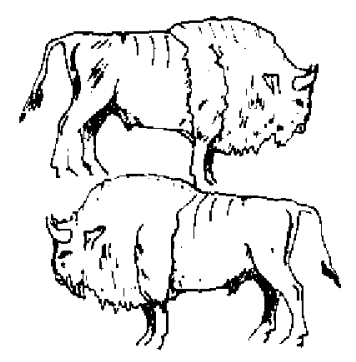

A
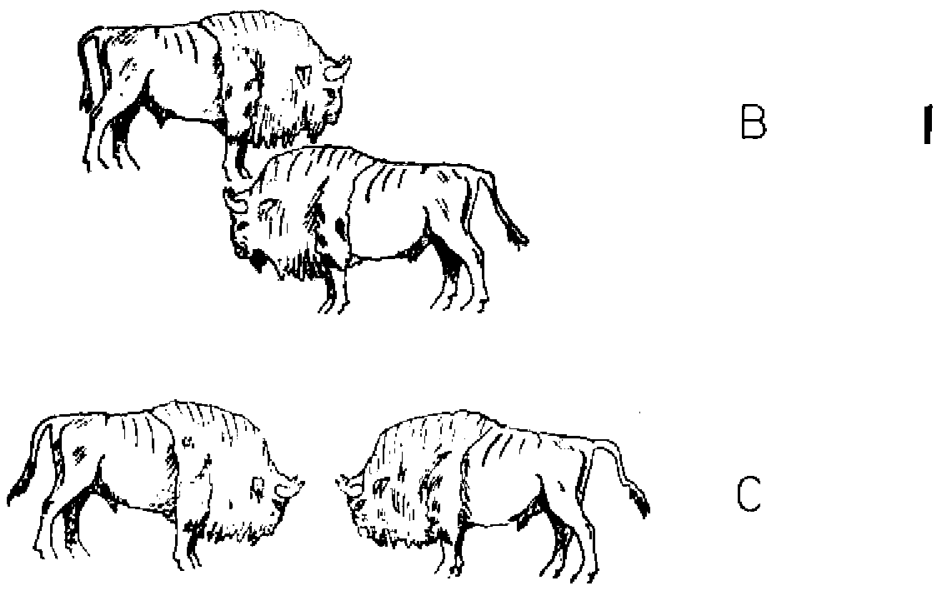

C

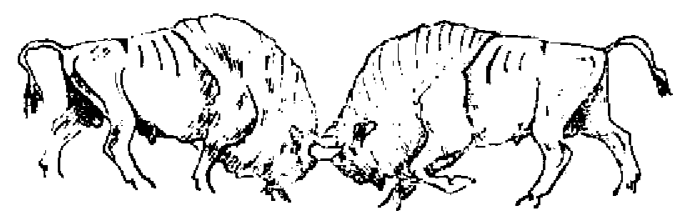

D

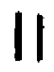

Fig. 5. Scheme of postures adopted by bulls figthing in the breeding period. I - initial phase, II - true fight. 
fight. The defeated bull was standing for a while on the spot, and then left at a slow pace. The tending bull lay down in shrubs at 13.45 , and two hours later he came back to the cows and lay down again. After an hour, he got up, overturned a small spruce and uprooted it with his horns, and then started feeding. At 17.45, two groups marged. In the newcoming group the other bull was present. He was in condition similar to that of the winner. The new bull approached the winner, shook his head several times, and circled him, but the latter did not respond, standing motionless. Finally at 18.00 the previous winner went away slowly, and the newcomer remained in the group.

The group did not react to the fight of bulls. Group members were foraging or resting nearby during the fight. The looser demonstrated his defeat by going away from the group and typically he was not pursued by the winner. Frequently wounded animals were observed after fighting, and sometimes these wounds resulted in death.

\subsection{Other Types of Belavior}

\subsubsection{Vocalization}

Vocalization as a form of communication between individual animals or within a group seems to be rather limited in bison. Cows utter the grunt while feeding, when small calves are resting nearby, and these are probably contact calls. They respond to their mothers in a similar way, and it may be suggested that these calls are individually differentiated. Using a similar grunt, the cow calls upon her calf to feed it, causing a quick response of the calf. For human ear these sounds are indistinguishable. Bulls in rut utter a characteristic threat grunt. They also utter other sounds like puffing and snorting. Sounds uttered by bison are not loud, and usually the sounds of a moving or foraging group can be heard first, and then the sounds uttered by animals indicative of the presence of cows with calves or an excited bull.

\subsubsection{Leadership}

A leading cow is a permanent component of the organization of mixed groups of European bison. Under natural conditions it is not always easy to notice her presence in the group, and the same is true of the hierarchical relationships in the group. Typically this is an older cow rearing a calf. Leading cows can markedly differ in temperament. 
Some of the leading cows of the mixed groups under study were gentle, tolerant of the observers ("Babula") and some were alert, often attacking the approaching observers ("Pocieszna"). The latter demonstrated aggression in the years when she had a calf and also in the years when only calves of other cows were present in the group.

The observations carried out so far do not provide a complete answer to the question how permanent the position of a leader is. It has been found, however, that some cows led groups for many successive year's. In one case the cow "Babula" lost the leading position for two years at an age of 21 years, when she was barren. But as soon as she gave birth to her last calf in 1983, she restored the leadership. In 1982 and 1984 , when she had no calves, she was staying outside the group for long periods, walking alone and not joining other groups. She solitary died at a distance of about $15 \mathrm{~km}$ from the home range of the group.

The leader of the group can be exchanged. This can happen when groups are merging. It was observed many times that if the cow " $\mathrm{Ba}$ bula" was present in one of the merging groups, she always became the leader of the whole new group. It seems that the rank of the leader is related to age, predisposing one of the cows to this position. The attitude of the leader towards an observer influenced the rest of the group. A quite responce of the leader accounted for resuming the interrupted activity by the group after the first-moment fleeing. Nervous response of the leader "Pocieszna" spread to the rest of the group, and most often the animals fled from the observer.

\subsubsection{Response to Man}

Bison herds usually flee from an approaching man. The reaction of bison largely depends on the circumstances of an encounter, the response of the leader, and the degree of restless of the animals. The leading cow apparently influences the response of the group. An example can be here the cow "Babula" and her quiet response to encounters with man. When the animals are harassed by insects, they are more inclined to flee from a man. The long-term observations of some groups markedly lowered the threshold of the response. The escape distance was reduced, and after several minutes the observers could stay near the group and the animals were continuing their normal activity.

The group of bison usually demonstrates aggression to man when they feel threatened. When a man is approaching a group with calves, aggression is exhibited by cows rearing calves, and especially by the leading cow. Presumably the presence of calves reduces the possibility of 
escaping for the whole group, and additionally stimulates the response of cows.

Bulls in rut demonstrate to man reactions typical of sexual excitment. Thus, they express their fear by shaking the heads, turning up the ground with hoofs, switching the tail, and threat grunting. During the eight-year period of the study we were forced to run away from attacking bulls on several occasions. Also some of the inhabitants of this region were attacked by solitary bulls in rut.

\subsubsection{Escape}

Scared bison start galloping and are running away fast on a short distance of about $100-150 \mathrm{~m}$. Then they stop and usually form a tight group. Groups with a high proportion of juveniles are more shy. Bison rarely run away when an observer is apploaching them cautiously in an open area, but they always escape when they are threatened from two sides. They do not run away from passing cars, tractors, or trains to which they got used. But a helicopter caused a panic escape of the group.

\subsubsection{Response to Thunder-storm}

Two times bison were observed during a thunder-storm with a strong wind and a shower. They formed a tight group and individual animals were standing in the direction towards which the wind was blowing. After the storm they lay down to have a rest. Moderate rainfall does not interrupt foraging or resting of the group.

\section{DISCUSSION}

\subsection{Activity Palterns}

The activity patterns of European bison described in this paper seem to be characteristic of groups living under natural conditions. Presumably they are similar to the patterns exhibited by bison living in the Bialowieża Forest in the past century, before the extinction of the original stock. It is difficult, however, to provide a direct evidence of this because the methods used by Karcov (1903) and Wróblewski (1927) do not satisfy the recent requirements concerning investigations into this problem. Wroblewski (1927) stressed that before World War I, food resources were inadequate for supporting the bison living there. At that time the Bialowieża Forest was a representative hunting area, and it was not exploited 
for timber. The tree stand was thus dominated by old trees. A similar situation occurs at present in the eastern part of the forest, which is in the Soviet Union. According to Koročkina (1972), free-living bison in the eastern part of the Bialowieża Forest allocate much more time for feeding than the study bison. In spring and autumn, bison were feeding for a maximum of $96 \%$ of their active time $(80 \%$ on the average), and in mid-summer 70\% on the average (Korockkina, 1972). According to Okolów (1970), eastern part of the Białowieza Forest is dominated by poorer forest sites. Presumably, the reduction of food resources in these habitats is also due to a lower proportion of young plantations and thickets as compared with that in the Polish part of the forest.
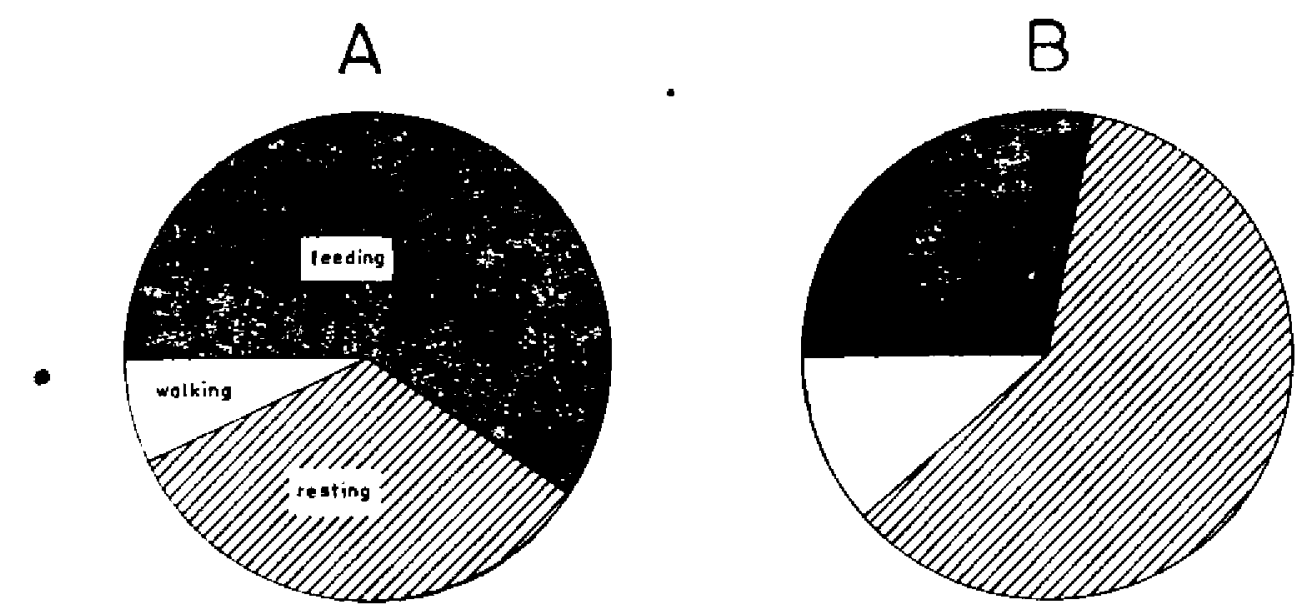

Fig. 6. Comparison of the daily activity of bison (in percentage of time) during the period without snow cover (A) and in winter (B) (winter time after Cabon-Raczyńska et al., 1983).

As in the Bialowieża Forest additional food is supplied for bison in winter, the time allocated for feeding is reduced to $30 \%$ of the total activity of these animals (Cabon-Raczyniska et al., 1983), while an opposite situation exists in the period without snow cover (Fig. 6). This is similar to the situation in enclosure, where food is supplied in excess (Vejner, 1980).

The proportion of daily activity allocated to feeding varies according to weather, among other things. Hot weather can account for prolongation of resting at the expense of feeding. Similar observations were made by Koročkina (1972) for European bison and by Herrig and Haugen (1976) for American bison.

The rhythm of the daily activity of bison is polyphase, thus typical of ruminants, in which feeding phases alternate with resting phases, used 
mostly for chewing. Such an activity rhythm was also observed in bison living in large enclosures (Van den Brink, 1980).

The sequence and duration of different phases of the daily activity can vary, except for the first and the last feeding phases taking place at dawn and 1--2 hours before dusk, respectively. A similar situation was observed in roe deer (Cederlund, 1981) and in red deer (Georgi, 1980). But in American bison, the phases of daily activity are rather stable for mixed groups and more variable for bulls (Shult, 1972). Timing of the first and the last feeding during the day is the same in the European and American bison.

The main forms of behavior are highly synchronized in mixed groups, indicating that groups are functioning as structural units of the bison population. Common feeding in groups enables bison to forage while moving (Krasinska et al., 1987). A similar synchronization in foraging hehavior was described by Shult (1972) in American bison Bison bison (Linnaeus, 1758). The whole group started feeding or resting concurrently within $15-40$ minutes. In winter aggregations of bison at feeding places the only highly synchronized activity was walking to a watering places (Cabon-Raczyńska et al., 1983). The other torms activity were of a more individual character.

\subsection{Behavioral Patterns}

\subsubsection{Feeding Behavior}

T'he diet of European bison consists of three main components: vegetation of the herb layer (grazing), twigs and leaves (browsing) and bark of trees (barking). There is a general agreement that vegetation of the herb layer predominates in the diet (Wróblewski, 1927; Borowski \& Kossak, 1972; Koročkina, 1972). In his classification of ruminants, which is based on a comparative analysis of the morphology of the alimentary tract, Hofmann (1978) included bison, together with the American bison, water buffalo (Bubalus bubalis) and caltle, to a specialized group of herbivores digesting grassy and fibrous food taken in large amounts with little selection. Such an approach is confirmed by a small feeding specialization of bison (Borowski \& Kossak, 1972; Koročkina, 1972).

There are some discrepancies in the estimates of proportions of different components in the diet. Borowski \& Kossak (1972) have found that browsing accounts for $33 \%$ of the diet biomass in the growing season and grazing for the remaining $67 \%$. In the present study we measured the proportions of lime spent browsing and grazing. The respective proportions were $4.8 \%$ and $95.2 \%$. Browsing was observed 
mainly in June and July, i.e. the period of the highest nutritive value of twigs and leaves (Drożdz, 1979). In the period without snow cover, barking was clearly seasonal, and occurred mostly in April, when the herb layer was not developed yet. But bison were barking trees throughout winter, most frequently when going to watering places (Caboí-Raczyńska et al., 1983). Comparative data for American bison (McHugh, 1958) show that browsing is even less important in the prairie, and barking is intensified in winter.

Continuous observations of the activity of bison confirmed the earlier conclusion of Krasinska $e t$ al. (198), obtained by the method of frequency of encounters, that bison prefer more than 20-year-old stands. These results differ from those of Borowski \& Kossak (1972) obtained by the method of recording feeding permanent sample plots in the Bialowieza Forest. These authors observed the predominance of thickets and young plantations as feeding sites of bison. Probably their method of counting traces of feeding on sampling plots yielded little representative results for the intensity of feeding in different habitat types. The proportions of different age classes of the stands have not noticeably changed since then to the time of the present study.

The present type of management of the Bialowieża Forest (selective cutting: small clearcuts of $0.08-0.12$ ha) is suitable for bison with respect to their feeding habits. Also Falinski \& Falinska (1986) indicate that bison largely use different forest habitats when food supply in them is increasing, including clearcuts and young plantations. It should be emphasized, however, that bison are associated with forests, prefering dense stands, and especially timber stands, for feeding. 'They spend in such habitats up to $80 \%$ of the feeding time, taking mostly herbaceous plants (about 70\% of the food biomass according to Borowski \& Kossak, 1972).

6.2.2. Other Types of Behavior

Many forms of the behavior of European bison, such as drinking, eliminative behavior, grooming, playing, or agonistic and sexual behaviors shows much similarity to the respective forms of the behavior of American bison (McHugh, 1958; Fuller, 1960; Egerton, 1962; Shackleton, 1968; Fischer, 1976; Ilerrig \& Haugen, 1976; Shult, 1972; Lott, 1981). When investigated in detail, they show some differences, but they can be explained by the fact that these animals live in different habitat types. It is especially the case of the bison inhabiting prairies.

In European bison occurring in mixed groups no regular visits to watering places were, observed, which occur in American bison. Fuller 
(1960) and Shult (1972) have found that mixed herds of American bison visited watering places at least once a day. American bison bulls from one populations visited watering places regularly (McHugh, 1958; Herring \& Haugen, 1970), and from other populations irregularly (Fischer, 1976). These differences can result from differences in the water content between plants growing in prairies and forests. In open areas of prairies evaporation is greater than in forests, where relative air humidity is high, rainfall is high, rainfall water is present on the floor for a long time, and also dew on mid-forest openings can persist even by noon, especially in the second half of summer. Thus, feeding animals take water in both these forms, and this should largely cover their needs. A frequent water intake by bison on hot days and lack of visits to watering places on rainy days provide evidence for this explanation. In winter, when bison are living on dry focd (hay) they visit watering places regularly every day, and also take water in the form of snow (Cabon-Raczyniska et al., 1983).

Wallowing, which is a component of the grooming behavior, is very similar in European and American bison. Individual differences occur in the frequency of wallowing. Shult (1972) observed that American bison bulls were wallowing more often than cows, juveniles and calves. In our observations the frequency of wallowing in bulls of European bison increased in the rutting period. 'This was not observed in American bison (Reinhardt, 1985).

European bison do not utter sounds comparable to roaring of bulls of American bison in the mating period, as described by Shult (1972) Herring \& Haugen (1976) or Lott (1981). In this period, bulls of European bison utter threat grunt, which is not loud, and was not noted in American bison more than 5 years old (Shull, 1972).

Small differences between European and American bison were found with respect to the age of breeding bulls. Experiments made in enclosures showed that bulls of the Liuropean bison reach sexual maturity early (Krasiński \& Raczyński, 1967), but free-living bulls start reproduction at an age of $7-8$ years. Among 15 marked bulls, the effective participation in mating was recorded for individuals 7 years old. Egerton (1962) and Shult (1972) have found that bulls of American bison do not form tending bonds up to an age of 5 years. According to Lott (1981), bulls start mating when 6 years old, thus one year younger than European bison.

There are differences in the behavior of cows in rut between European and American bison. Rutting cows of the American bison demonstrate their excitment by a high mobility, running among the group members, and stimulating the bull (Lott, 1981). This is not the case of the cows of 
European bison, no matter whether enclosed of free living (Krasinski \& Raczyński, 1967). The indicator of their physiological condition is the reaction of bulls, so-called accompaning. Lott (1981) suggests that in large groups of the American bison, comprising 100-200 individuals in the rutting season, the behavior of cows in rut stimulates competition among mature bulls. Presumably in much smaller groups of European bison there is no need for such a stimulation.

Females of the American bison can often be hurt with hoofs of the bulls during mating (Lott, 1981). Such facts have not been noted in cows of the European bison.

\subsection{Social Relationships}

The dominance structure of bison was analyzed in detail only for animals living in zoological gardens (Vajner, 1980) or in enclosures (Van den Brink, 1980; Krischke, 1983). These analyses concerned artificial groups made up of one adult bull, several cows, and their offspring. Such groups were dominated by the bull, this being the case also in Bialowieza enclosures.

In the wild, bison typically live in mixed groups representing basic structural units of the population. In the breeding season these groups are joined by one or several bulls more than 6 years old. In the prerutting season, young 4-5-year-old bulls usually stay in mixed groups, whereas more than 6-year-old bulls form bull groups or are solitary (Krasiński, 1978).

Hierarchical structure of mixed groups is relatively stable. Interactions among cows were rarely observed, and most of them did not fight at. all; they only displayed signals confirming the existing hierarchy. Over the study period only one fight was observed between cows, which could be related to their social rank in the group. During encounters of two groups and their temporary merging, no aggressive behavior was observed which could be indicative of attempts at forming a new dominance structure. It seems that in mixed groups the age of their members is the main factor determining the dominance position of cows, like it is the case in American bison (Rutberg, 1983). In few cases when the leading cows were known ("Babula" and "Pocjeszna"), these were the oldest cows. Probably this is the same situation as that described by Lott (1981) for American bison, where competition in the group of cows is unjustified with respect to fitness benefits.

Sexually mature young bulls aged 4- -6 years are not dominants in mixed groups for most of the season without snow cover. Similarly, the reproducing bulls (more than 6 years old), which temporarily stay in mised groups during the breeding season, do not disturb the domi- 
ilance structure of the group, and their presence in the group concerns only their reproductive function. They have a higher social rank, however, than the young bulls. Their interactions with the other members of the group are usually passive.

In mixed groups there occur an exchange of bulls both young and older, participating in reproduction. The exchange of the latter can be preceded by fighting. The arrival of one or several bulls to the group need not be coupled with leaving the group by the former dominant, but it accounts for development of a new dominance structure among bulls. Such a social organization of a group with a natural age and sex structure ensures that the cows in oestrus have been impregnanted. The competitive mechanisms in bulls in the European bison during the breeding season are thus different from those described by Lott (1979, 1981) for the American bison. These differences are due to the facts that the rutting period is extended up to two months in the European bison (2-3 weeks in the American bison, Lott 1981), and the structure and size of groups during the breeding season are different for the American and European bison. In the European bison, competition among bulls is extended for a longer period during which an exchange of mature bulls can occur. This does not change, however, the general rules of the reproductive strategy of bulls, probably promoting bulls of a high social rank as successful breeders, like it is the case of the American

bison. These facts shown that during the breeding season in free-living group of bison, unlike in those in enclosures or zoological gardens, the sexual selection governed by the biological and ecological rules occurs.

The results of our comparison of the behavior of the European bison and American plains bison incline us to support the view of Bohlken (1967) that these two forms are closely related. Also recent craniometric analysis of the contemporary forms of the genus Bison (Zyll de Jong (1986)), showed that the European bison and American bison are conspecific, and more, that differences between $B, b$. bison and ${ }^{-} \cdot$ b. bonasus are smaller than between either of them and $B$. $b$. athabasene Rhoads, 1398.

\section{REFERENCES}

1. Bohlken H., 1967: Beitrag zur Systematik der recenten Formen der Gattung Bison H. Smith, 1827. Z. zool. Syste. Evolutionsforsch. 5, 1: 54-110.

2. Borowski S. \& Kossak S., 1972: The natural food preferences of the European bison in seasons free of snow cover. Acta theriol., 17: 151-169.

3. Brink Van den W. J., 1980: The behaviour of wisent and bison in larger enclosures. Acta theriol., 25: 115-130.

4. Caboń-Raczyńska K., Krasińska M. \& Krasiński Z, 1983: Behaviour and dály 
activity rhythm of European bison in winter. Acta theriol., 28: 273-299.

5. Cederlund G., 1981: Daily and seasonal activity pattern of roe deer in a boreaI habitat. Viltrevy, 11: $315-353$.

6. Dróżdż A., 1979: Seasonal intake and digestibility of natural foods by roe deer. Acta theriol., 24: 137-170.

7. Egerton P. J. M., 1962: The cow-calf relationship and rutting behavior in the American bison. University of Alberta: Master's thesis. Department of Zoology: 1-155.

8. Falinska K., 1973: Dynamika sezonowa runa zbiorowisk leśnych Bialowieskie.. go Parku Narodowego. Phytocenosis, 2: 1-121.

9. Falinski J. B. \& Falinska K., 1986: Vergetation dynamics in Bialowieża Forest. Ecological studies in lowland primeval forest. Dr W. Junk Publishers: 1-537. Dordrecht, Boston, Lancaster.

10. Fischer A. W., 1967: Observations on behavior of lone bull bison. Proc. Iowa Acad. Sci., 74: 87-91.

11. Fuller W, A., 1960; Behavior and social organization of the wild bison of Wood Buffalo National Park. Canad. Aretic, 13: 1-19.

12. Georgii B., 1980: Type d'activité du Cerf (Cervus elaphus L.) en tonetion de la structure du biotope. Ciconia, 4: 35-41.

13. Herrig D. M. \& Haugen A. O., 1970: Bull bison behavior traits. Proc. Iowa Acad. Scl, 76: 245-262.

14. Hofmanı R. R., 1978: Die Stellung der Europäischen Wildwederkatter in System der Asungstypen. [In: "Wildbiologische Informationen für den Jäger", Hofmann R. R, ed]. Jagd + Hege-Verlag: 1-142. St Gallen.

15. Karcov G., 1903: Belověskaja Pušca. Artist. Zaved, AF Marksa: 1-414 S-Petersburg.

16. Koro"kina Is. N., 1972: Sutočnyi ritm aktivnosti zubrov Belovežsknj pušri. Bielovežskaja pušča. Issledovanija, 6: 125-131.

17. Krasińska M., Caboń-Raczyńska K. \& Krasinski Z., 1987: Strategy of habitat utilization by Eulopean bison in the Bialowieża Forest. Acta theriol, 31: 147-40:3.

18. Krasiński Z. A., 1978: Dynamics and structure of the European bison population in the Bialowieża Primeval Forest. Acta theriol., 23: 3-48.

19. Krasiński 7. A., 1978a: Restytucja i ewolucja wolnych populacji żubrów $w$ Polsce. Czlowiek i Nauka: 207-229.

20. Krasinski Z. \& Raczyński J, 1967: The reproduction biology of the European bison livins in reserves and freedom. Acta theriol, 12: 407--444.

21. Krischke N., 1984: Beiträge zum Sozlalverhalten des Wisents (Bison bonasus bonastus L.). Z. Säugetierkde., 49: 43-54.

22. Lott D. F., 1979; Dominance relations and breeding rate in mature male American bison. Z. Tierpsychol., 49: 418-432.

23. Lott 12. F., 1981: Sexual behavior and intersexual strategies in American bison Z. Tierpsychol,, 56: 97-114.

24. McHugh T., 1972: The time of the buffalo. A.A. Knopf: 1-339. New York.

25. Okolów Cz, 1970: Gospodarstwo rezerwatowo-lowieckie "Biełowieżskaja Pttszcows :Bison bison). Z. Tierpsychol., 63; 206-212.

26. Reinhardt V., 1985: Quantitative analysis of wallowing in a confined bison herd. Acta theriol., 30: 149-156.

27. Rutberg A, T., 1983: Factors influencing dominance status in American bison cows (Bison bison). Z. Tierpsychol., 63:200-212. 
28. Shackleton A. M., 1968: Comparative aspects of social organisation of American bison. The University of westem Ontario: 1-67. London. Canada.

29. Shult M. J., 1972: American bison behavior patterns at Wind Cave National Park. Iowa State University, Ph. D. Theses, Zool.: 1-178.

30. Vajner L., 1980: Etologická studie stł̇a zubru evropských Bison bonasus Linnaeus, 1758, v prä́ské ZOO. Gazella, 2: 59-69.

31. Wróblewski K., 1927: Zubr Puszczy Bialiwieskiej. Munografia. Wyd. Pol.: 1-232. Poznań

32. Zyll de Jong C. G., 1916: A systematic study of recent Bison with particular consideration of the Wood bison (Bison bison athabascae Rhoads 1898). Publications in Natural Sciences, 6: 1-69. Ottawa.

Received 2 October 1986, Acceptcd 23 December 1986

Krystyna CABOŃ-RACZYNSKA, Małgorzata KRASIŃSKA, Zbigniew A. KRASIŃSKI i Jan M. WOJCIK

\section{RYTM DZIENNEJ AKTYWNOSCI I BEHAWIOR ZUBROW W PUSZCZY BIALOWIESKIEJ W OKRESIE BEZ POKRYWY SNIEZNEJ}

\section{Streszczenje}

Prowadząc obserwacje ciągle od świtu do zmroku $\mathbf{w}$ ciągu trzech sezonów (1902-1984) bez pokrywy śnieżnej zbadano rytm dziennej aktywności zubiów $w$ grupach mieszanych oraz różne przejawy zachowań grupowych i indywidualnych.

Zubry przeznaczaja na żerowanie średnio $60,4 \%$ czasu dnia, na odpoczynek $31,9 \%$ i na przemieszczanie bez. zerowania $7,7 \%$ (Tabela 1). Rytm dziennej alitywności żubrów ma charakter wielofazowy - fazy żerowania trwajace $15^{\circ}-5 \mathrm{H} 15^{\prime}$ przeplatane sa odpoczyrkiem (15-4H15) lub ruchem (Ryc. 2 i 3). Sposiód czynnosici wykonywanych $w$ rytmie indywidualnym kosmetyka zajmuje od $1 \cdots 5 \%$, karmienie i pielęgnacja cielęciả $0,5-1,2 \%$ czasu dnia. Czas przeznaczony na zerowanie j odpoczynek u zwierząt tworzacych parę podezas rui jest obniżony u krowy o $20 \%$, a u byka $26,5 \%$ na rzecz zachowania seksualnego (Tabela 2). Caas zachowania seksualnego byków wydluża się $w$ zależnosici od fazy oestrus u samicy i liczby byków obecnych $w$ grupie mieszanej.

Zubry w brupach mieszunych przenieszczają się $w$ środowisku leśnym popizez różne typy lasu, zręby, uprawy, mlodniki, ląki śódleśne. Zerowanie na rumie zajmuje żubrom $95,2 \%$ czasu przeznaczonego na zerowanie (Tabela 3 ). $W$ czasie trwania sezonu wegetacyjnego niezależnie od typu siedliska leśnego runo przedstawia glówne zasoby zerowe żubrów. Zgryzanie Jiści i mładych pędów stanowi dość regularny, ale niewielki skladnik zeru, zajmując 2,9\% czasu ptzeznaczonego na żerowanie. Najmniej czasu przeznaczają zubry na spalowanie $\left(1,9^{0} \%\right)$, przy czym ma ono wyrażny charakter. Jest szczególnie intensywne jedinie wezesną wiosną (Tabela 4).

Niezaleźnie od typu siedliskowego lasu żubry więksiza część czasu dnia spędzajł żerując $w$ drzewostanach starszych niż 20 lat $(30,6 \%$ czasu żerowania), a na zrębach i uplawach $13,4 \%$ i w mlodnikach $6 \%$.

Przewolniczka $w$ grupie mieszanej jest krowa, na ogól starsza, prowadzaca cielę. Znane są krowy będące przewodniczkami przez kilka lat. 
Opisano zachowanie się żubrów pođczas pobierania pokarmu, wydalania, picia wody, zabaw, odpoczynku i przemieszczanla się.

Często obserwowano czasowe lączenie się kilku grup mieszanych, co w okresie pozarujowym na ogól zachođzi bez reakcji. W okresie godowym $w$ takiej sytuacji interakcje dotyczą najczęściej byków i prowadzą do wytworzenia wśród nich struktury dominacyjnej. Agresywne zachowanie wśród cieląt, mlodzieży i krów jest rzadkic. Obserwowane jest $u$ byka towarzyszącego krowie $w$ rui $w$ stosunku do innych byków.

Najsilniejszý związek matki z cielęciem występuje w pierwszym miesiącu życia. Jednorazowy czas ssania $u$ mlodych cielat $w$ okresie maj-lipiec wynosi średnio 4,2 $\pm 1,3$ min., a karmienie odbywa się kilka razy dziennie, natomiast $w$ okresie sierpień-październik czas tej czynności jest istotnie dluższy $-6,7 \pm 3,4$ min., ale odbywa się ono na ogól już tylko 2 razy dziennie (Tabela 5).

Zachowanie czyszczące u żubrów przebiega jako ocieranie się, wylizywanie, bicie ogonem $\mathrm{i}$ tarzanie. Tarzanie obserwowane jest częściej $\mathrm{u}$ sztuk doroslych $\left(82,6^{0} \%\right.$ obserwacji) niż u mlodzieży $\left(14,6^{0} \%\right)$ i cieląt $(2,82)$. W grupie doroslych, krowy tarzają się częściej $(56,5 \%$ obserwacji) niż byki $(26,1 \%)$. U byków ta forma zachowania nasila się $w$ sezonie godowym $72,7 \%$ tej aktywności u byków).

Zubrzyce znajdujące się $w$ rui nie demonstruja tego $w$ sposób widoczny swoim zachowaniem. Natomiast objawy zachowania seksualnego sameów w sezonie godowym wyraźnie nasilają się. Byki wtedy często lamią młode świerki, wyrywając ich korzenie rogami, lamią galęzie o które czochrają glowę, rozgrzebuja podtóce leśne przenimi kończynami i tarzają się. Krowie znajdującej się $w$ rui przez okres 1-2 dni towarzyszy byk. "Utworzona para znajduje slę na skr'ajtu grupy a byk wykazuje różnorodne objawy asystowania, koniczące się pokryciem krowy. Gdy w tym okresie do grupy dolącza inny, dorosly byk, który może zagrozić pozycji dominanta, może dojść do walki, która trwa okol 15 minut.

Wysoka synchronizacja glownych form zachowania czlonków grupy mieszanej w okresie bez pokrywy śnieżnej jest wysoka i świadczy o konsolidacji grupy podstawowej jednostki strukturalnej populacji. Wspólne żerowanie w grupie umożliwia realizację strategii pokarmowej żubrów, polegająca na aktywnym żerowaniu $w$ ruchu. Nie obserwowano tego podezas zimy kiedy żubry korzystaja z pokarmu podawanego przez czlowieka przy brogach.

Stwierdzono istnienie generalnego podobienstwa zachowania zubrów i bizonow. Bytowanie $w$ odmiennych warunkach środowiskowych wplywa na różnice $w$ strukturze socjalnej i wielkości ugrupowań. Dotycza one na przyklad braku u żubrów regularności odwiedzania wodopojów oraz póżniejszego uczestniczenia byków $w$ rozrodzie. U krów żubra brak wyraźnego demonstrowania stanu rui co ma miejsce u bizona. Stala struktura socjalna krów i zmienna u byków mą charakter przystosowawczy j sprzyja bezpieczenstwu stada oraz realizowaniu swobodnego doboru plciowego. 